\title{
Solid Oxide Fuel Cells: Systems and Materials
}

\author{
Ludwig J. Gauckler*, Daniel Beckel, Brandon E. Buergler, Eva Jud, Ulrich P. Muecke, Michel Prestat, \\ Jennifer L.M. Rupp, and Jörg Richter
}

\begin{abstract}
A solid oxide fuel cell (SOFC) is a solid-state energy conversion system that converts chemical energy into electrical energy and heat at elevated temperatures. Its bipolar cells are electrochemical devices with an anode, electrolyte, and cathode that can be arranged in a planar or tubular design with separated gas chambers for fuel and oxidant. Single chamber setups have bipolar cells with reaction selective electrodes and no separation between anode and cathode compartments. A nickel/yttria-stabilized-zirconia (YSZ) cermet is the most investigated and currently most widespread anode material for the use with hydrogen as fuel. In recent years, however, doped ceria cermet anodes with nickel or copper and ceria as the ceramic phase have been introduced together with ceria as electrolyte material for the use with hydrocarbon fuels. The state-of-the-art electrolyte material is YSZ of high ionic and nearly no electronic conductivity at temperatures between $800-1000{ }^{\circ} \mathrm{C}$. In order to reduce SOFC system costs, a reduction of operation temperatures to $600-800^{\circ} \mathrm{C}$ is desirable and electrolytes with higher ionic conductivities than YSZ are aimed for such as bismuth oxide, lanthanum gallate or mixed conducting ceria and the use of thin electrolytes. Proton conducting perovskites are researched as alternatives to conventional oxygen conducting electrolyte materials. At the cathode, the reduction of molecular oxygen takes place predominantly on the surface. Today's state-of-the-art cathodes are $\mathrm{La}_{\mathrm{x}} \mathrm{Sr}_{1-\mathrm{x}} \mathrm{MnO}_{3-\delta}$ for SOFC operating at high temperature i.e. $800-1000{ }^{\circ} \mathrm{C}$, or mixed conducting $\mathrm{La}_{x} \mathrm{Sr}_{1-x} \mathrm{Co}_{y} \mathrm{Fe}_{1-y} \mathrm{O}_{3-\delta}$ for intermediate temperature operation, i.e. $600-800{ }^{\circ} \mathrm{C}$. Among the variety of alternative materials, $\mathrm{Sm}_{x} \mathrm{Sr}_{1-x} \mathrm{CoO}_{3-\delta}$ and $\mathrm{Ba}_{x} \mathrm{Sr}_{1-x} \mathrm{Co}_{x} \mathrm{Fe}_{1-x} \mathrm{O}_{3-\delta}$ are perovskites that show very good oxygen reduction properties. This paper reviews the materials that are used in solid oxide fuel cells and their properties as well as novel materials that are potentially applied in the near future. The possible designs of single bipolar cells are also reviewed.
\end{abstract}

Keywords: Anode $\cdot$ Cathode $\cdot$ Electrolyte $\cdot$ Materials $\cdot$ SOFC

\section{Introduction}

Fuel cells are one of the most attractive energy conversion systems because they offer high efficiency and low pollution. An advantage of fuel cells is the decentralised generation of electricity and the prospective applications in mobile devices.

\footnotetext{
${ }^{\star}$ Correspondence: Prof. Dr. L.J. Gauckler Nonmetallic Inorganic Materials Department Materials Swiss Federal Institute of Technology Wolfgang-Pauli-Str.10

$\mathrm{CH}-8093$ Zurich

Tel.: +411632 5646

Fax: +4116321132

E-Mail: ludwig.gauckler@mat.ethz.ch
}

A fuel cell is an electrochemical device that can convert chemical energy of a fuel and an oxidant into heat and electric power. In solid oxide fuel cells (SOFCs) the electrolyte consists of an oxygen ion conducting ceramic such as yttria-stabilized zirconia (YSZ). One advantage of SOFCs is their possibility to directly use natural gas and the high reaction rate given by the high operating temperature. Thus, no expensive catalysts are needed. However, the ceramic materials of the SOFC are difficult to process and not easy to assemble.

A schematic of a SOFC is shown in Fig. 1. A single cell consists of three basic elements: electrolyte, anode and cathode. The cathode and anode electrodes are porous layered ceramic (cathode) and ceramicmetal (anode) components enabling easy gas diffusion to and from the electrode-electrolyte interfaces. They exhibit high electronic conduction and preferably also ionic conduction. The reduction and oxidation at the cathode and the anode respectively are spatially separated and the electrons are forced to flow through an external circuit. At the electrodes, the charge carrying species is changed from electrons from the outer circuit to the charged species the electrolyte can conduct. In the SOFC the electrolyte conducts $\mathrm{O}^{2-}$-ions. The driving force for the migration of $\mathrm{O}^{2-}$ is the oxygen chemical potential gradient between the anode (low) and cathode (high). At the cathode, side air is usually used corresponding to an oxygen partial pressure $\left(\mathrm{p}_{\mathrm{O} 2}\right)$ of $0.21 \mathrm{~atm}$. At the anode, the $\mathrm{p}_{\mathrm{O} 2}$ is very low due to the consumption of oxygen ions by the used fuel (in most cases hydrogen) to form water. The operating temperature of a SOFC is between 500 and $1000{ }^{\circ} \mathrm{C}$ because the conduction of oxygen ions in the solid electrolyte is a thermally activated process. In contrast to other fuel cell types, a solid oxide fuel cell can be operated with a variety of fuels such as $\mathrm{CH}_{4}$ with steam reforming and within a wide temperature range $\left(500-1000{ }^{\circ} \mathrm{C}\right)$.

At the cathode, electrochemical reduction of oxygen occurs and the oxygen ions 


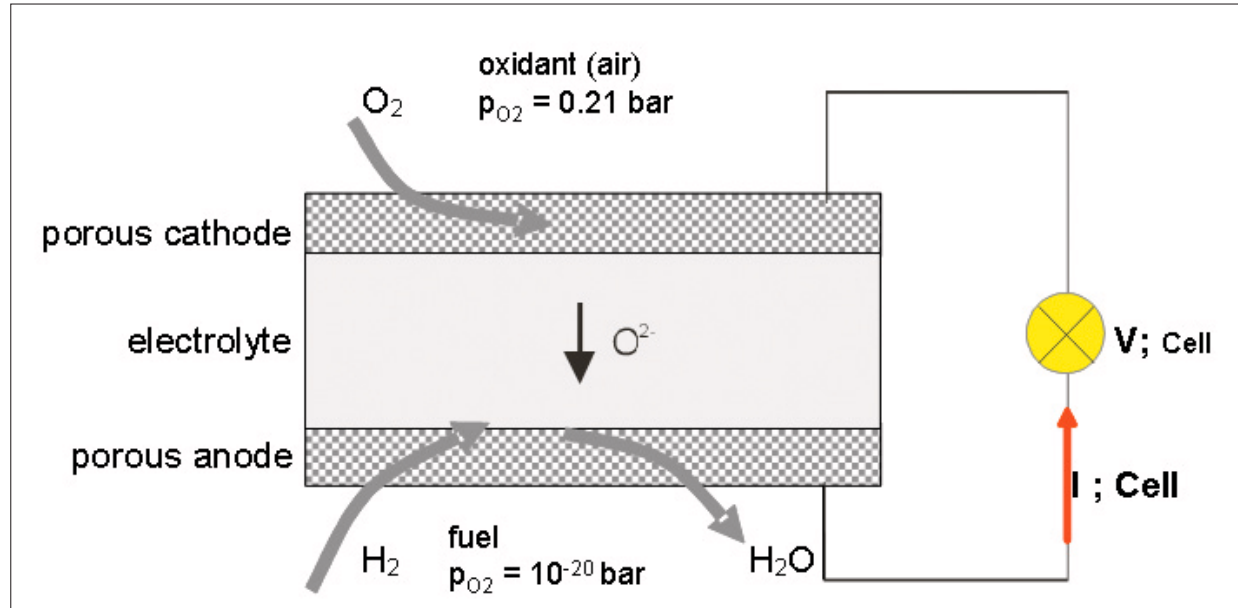

Fig. 1. Schematic of a solid oxide fuel cell (SOFC) element with anode, cathode and electrolyte

migrate through the electrolyte via a vacancy mechanism to the anode. At the anode, hydrogen is electrochemically oxidized to water. Each cell delivers a maximum of $1 \mathrm{~V}$ and is typically operated at around 0.6 to $0.7 \mathrm{~V}$ at a power output of typically 250 to $450 \mathrm{~mW} / \mathrm{cm}^{2}$. In SOFC systems many cells are stacked in series connected with a metallic conducting interconnect.

Research and development in the field of SOFC are currently concentrating on lowering the operating temperature in order to reduce costs and increase lifetime and to increase reliability of the ceramic stack elements and interconnects. New manufacturing technologies are demanded when thin electrolytes are used reducing the electrical resistance of the cell. Materials as well as systems development aim also for better fuel utilization and higher electrical efficiency.

This paper reviews the different possible designs of SOFC cells including the possibilities when reaction selective electrodes are used. Commonly used materials and some of their properties, as well as novel materials that could be applied in near future are also reviewed as well as a search strategy for those materials.

\section{Design}

The design of a single cell is closely related to the design of an entire stack. Because a single cell only delivers $1 \mathrm{~V}$, more than one cell is usually connected in series using interconnects. The open circuit voltage (OCV) of the SOFC, i.e. the voltage of the system when no current is flowing, corresponds to the number of individual cells in the stack. Over the last two decades, SOFCs based on yttria-stabilised zirconia have been developed for an operating temperature range of $900-1000{ }^{\circ} \mathrm{C}$. The advantage of the high temperature is that internal reforming of hydrocarbons is possible directly on the anode without the need for an external reformer [1].

One important design criterion for a solid oxide fuel cell is the separation of anode and cathode by the gas tight electrolyte. Pinholes or cracks in the electrolyte can cause the hydrogen to leak to the cathode compartment where it reacts directly with oxygen. This will decrease the open circuit voltage $(\mathrm{OCV})$ and might even render the fuel cell inoperable. The development of a suitable stack sealant still presents a challenging task because the requirements for the sealants are stringent due to harsh environments and the high operating temperatures. Sealing of SOFCs can be done by using bonding seals or pressurized seals. For bonding seals materials like high- $\mathrm{B}_{2} \mathrm{O}_{3}$ glasses [2], earth-alkali silicate glasses such as $\mathrm{BaOAl}_{2} \mathrm{O}_{3} \mathrm{SiO}_{2}$ [3] or glass ceramics are commonly used. Another solution relies on compressive seals based on mica that do not bond chemically to the SOFC materials [4].

\subsection{Tubular Design}

In the 1960s experimental SOFCs with planar geometry were evaluated and it was found that it is very difficult to obtain adequate gas sealing at the edges of the cell, Siemens-Westinghouse solid oxide fuel cell

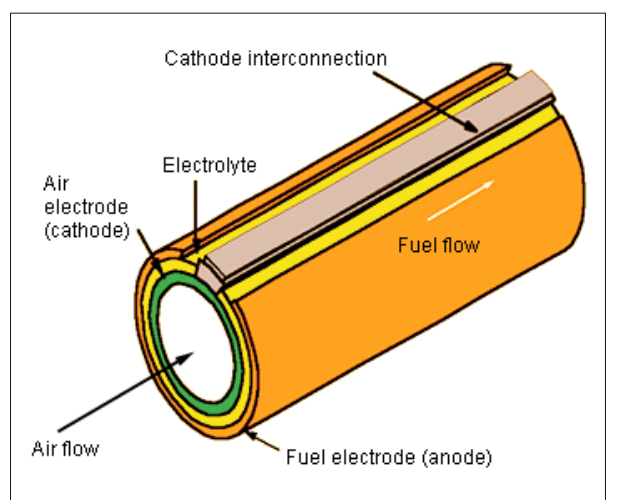

Fig. 2. The tubular design from Siemens-Westinghouse

mainly due to the mismatch of thermal expansion coefficient between the electrolytes and support structures and the mechanical properties of the sealing materials. In order to overcome these problems a tubular configuration (i.e. cylindrical design) was developed by Westinghouse and taken over by Siemens and improved over the last 20 years. In this design (Fig. 2) the electrolyte and anode are supported on a thick cathode tube that is closed at one end. The materials, their dimensions, and fabrication processes are summarized in Table 1. The electrolyte is deposited onto the cathode support after fabrication of the interconnection. In a last step, the anode is applied. The gas manifold of the Siemens-Westinghouse design is illustrated in Fig. 3. Air is introduced via a central $\mathrm{Al}_{2} \mathrm{O}_{3}$-tube to the end of the cathode tube. The oxidant flows back across the cathode while the fuel flows in the same direction at the exterior of the tube. At the plenum of each cell, the depleted flow of air and fuel recombine and the remaining active gases react. The generated heat serves to preheat the incoming oxidant stream. One of the most attractive features of this fuel cell design is that it eliminates the need for leakfree gas manifolding of the fuel and oxidant streams in the hot zone. The drawback is that the electric current has to flow along the circumference of the tube in the anode and the cathode. This increases the length of the conducting path and thus the ohmic resistance of the cell as compared to a planar one.

Table 1. Materials and fabrication processes for state-of-the-art cathode supported cells of the

$\begin{array}{llll}\text { Component } & \text { Material } & \text { Thickness } & \text { Fabrication Process } \\ \text { Cathode Tube } & \text { Doped } \mathrm{LaMnO}_{3} & 2.2 \mathrm{~mm} & \text { Extrusion-sintering } \\ \text { Electrolyte } & \mathrm{ZrO}_{2}\left(\mathrm{Y}_{2} \mathrm{O}_{3}\right) & 40 \mu \mathrm{m} & \begin{array}{l}\text { Electrochemical vapour } \\ \text { deposition }\end{array} \\ \text { Interconnect } & \text { Doped LaCrO}_{3} & 85 \mu \mathrm{m} & \begin{array}{l}\text { Plasma spraying } \\ \text { Anode }\end{array} \\ \mathrm{Ni}^{-}-\mathrm{ZrO}_{2}\left(\mathrm{Y}_{2} \mathrm{O}_{3}\right) & 100 \mu \mathrm{m} & \begin{array}{l}\text { Slurry spraying or electro- } \\ \text { chemical vapour deposition }\end{array}\end{array}$


Siemens-Westinghouse has been working on this problem and has come up with a new design that is called the high-power density SOFC (HPD-SOFC) [5]. In this design, shown in Fig. 4, a flat cathode tube with ligaments is used instead of a cylindrical one. It allows easier manifolding of air inside the tube and higher packing density of cells as compared to the cylindrical configuration. This leads to higher volumetric power densities of a complete cell stack. Most important is that the bridges within the cathode tube allow for shorter current

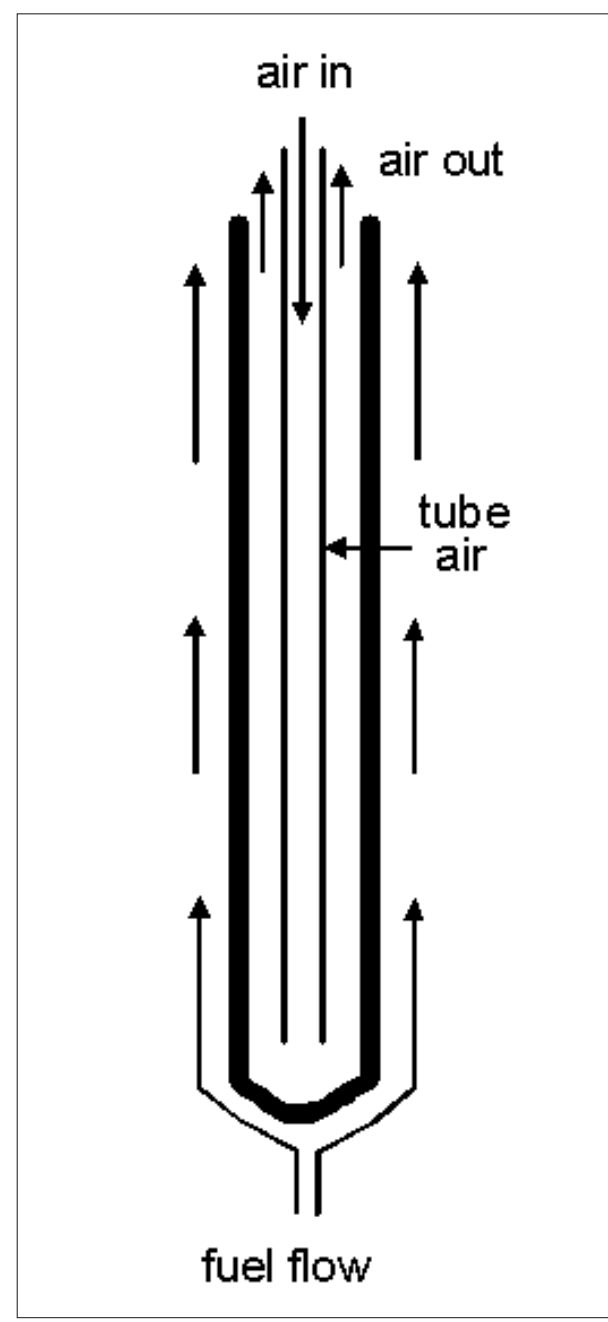

Fig. 3. Schematic view of gas flows in the Siemens-Westinghouse SOFC design

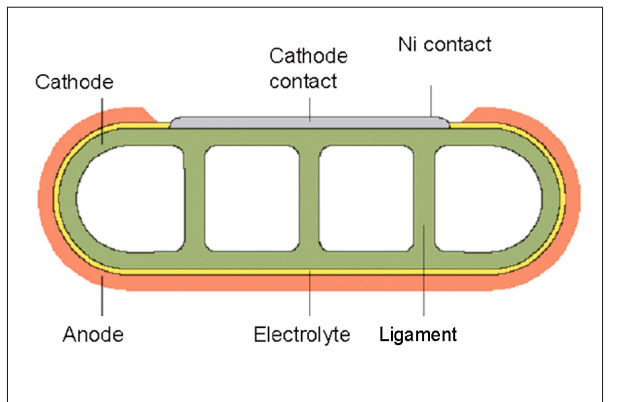

Fig. 4. Flat tube design by Siemens-Westinghouse paths, which in turn decrease the ohmic resistance of each cell and increase the power density of cell stacks. The Siemens-Westinghouse power systems are well established and development has shifted from basic technology to cost reduction and scale up [6].

\subsection{Planar Design}

A planar design of the bipolar plates enables the electrical connection of cells in series to be simplified without long current paths. Another advantage of the planar design is that low-cost fabrication methods such as screen-printing and tape casting can be used. However, because of thermal stresses, the size of the cells was limited in the past. Today $10 \times 10 \mathrm{~cm}^{2}$ planar cells can routinely be produced and operated [7]. Sulzer Hexis aims at building systems for the cogeneration of electricity and heat for residential applications in the $1 \mathrm{~kW}$ power regime with cells of planar design [8]. A single cell with endplate (top) and interconnect (bottom) is shown in Fig. 5. The fuel is fed into the centre of a cylindrical stack consisting of layered circular cells. Each interconnect serves as gas manifold and ensures that the reactant air is preheated. It is made via powder metallurgy of oxide dispersion strengthened alloy $(95 \% \mathrm{Cr}$ and $5 \%$ $\mathrm{Fe}$ ) with $1 \% \mathrm{Y}_{2} \mathrm{O}_{3}$. The materials, thicknesses, and fabrication processes of each component are given in Table 2. A crucial point is the metal/ceramic contact between the electrodes and interconnects, which is made at the cathode side by applying a LSC slurry to the pins of the interconnect and a $\mathrm{Ni}$ gauze at the anode side. To the exterior, the cell is not sealed and the unreacted fuel is burnt with the unreacted oxygen from air.
Currently the life of a fuel cell is in the order of 3000-7000 $\mathrm{h}$ and needs to be improved by optimizing the mechanical as well as electrochemical stability of the used materials [9].

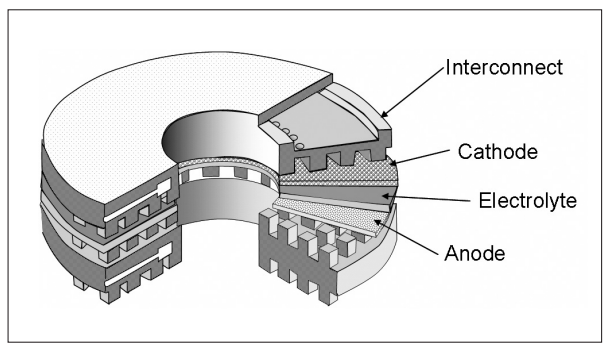

Fig. 5. Ring-type solid oxide fuel cell, with metallic interconnect from Sulzer Hexis

\subsection{Single Chamber Design}

Conventional fuel cells rely on the strict separation of fuel and oxidant by the electrolyte membrane and seals. By separating the fuel and oxidant, direct parasitic chemical reactions of fuel and oxidant are avoided. However, it has been shown that it is not mandatory to separate the fuel and the oxidant for operating a fuel cell: By using reaction-selective electrodes a fuel cell can be operated in a single gas chamber, fed by a mixture of fuel and air. Such a cell is often referred to as Mixed Gas Fuel Cell or Single Chamber SOFC (SC-SOFC).

Already in 1965 van Gool proposed a device using 'surface migration' of an inert substrate with two different electrodes [10]. The electronically insulating substrate should permit easy surface transportation of at least one of the reactants in ionic form. The electrodes are placed on the same side of this substrate and have different catalyt-

Table 2. Materials and fabrication processes of the components for the electrolyte supported Sulzer Hexis solid oxide fuel cell.

$\begin{array}{llll}\text { Component } & \text { Material } & \text { Thickness } & \text { Fabrication Process } \\ \text { Cathode } & \mathrm{LaSrMnO}_{3}(\mathrm{LSM}) & 20-100 \mu \mathrm{m} & \text { Screen printing } \\ \text { Electrolyte } & \mathrm{ZrO}_{2}\left(\mathrm{Y}_{2} \mathrm{O}_{3}\right)(\mathrm{TZP} / \mathrm{FSZ}) & 150-250 \mu \mathrm{m} & \text { Tape casting } \\ \text { Interconnect } & \mathrm{CrFe}^{2} \mathrm{Y}_{2} \mathrm{O}_{3} & & \text { Powder metallurgy } \\ \text { Anode } & \mathrm{Ni}^{-\mathrm{ZrO}_{2}}\left(\mathrm{Y}_{2} \mathrm{O}_{3}\right) & 20-100 \mu \mathrm{m} & \text { Screen printing }\end{array}$

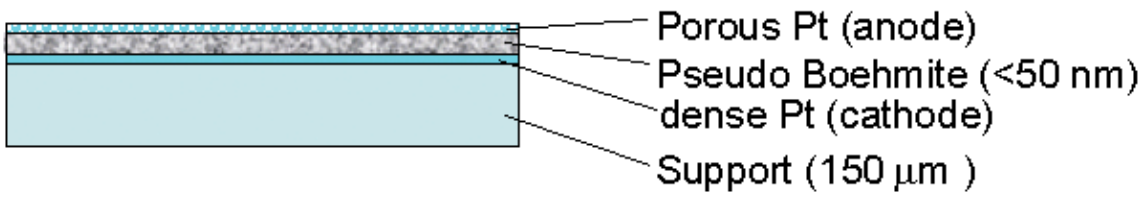

Fig. 6. The first single chamber fuel cell proposed by Dyer in 1965 [11] 


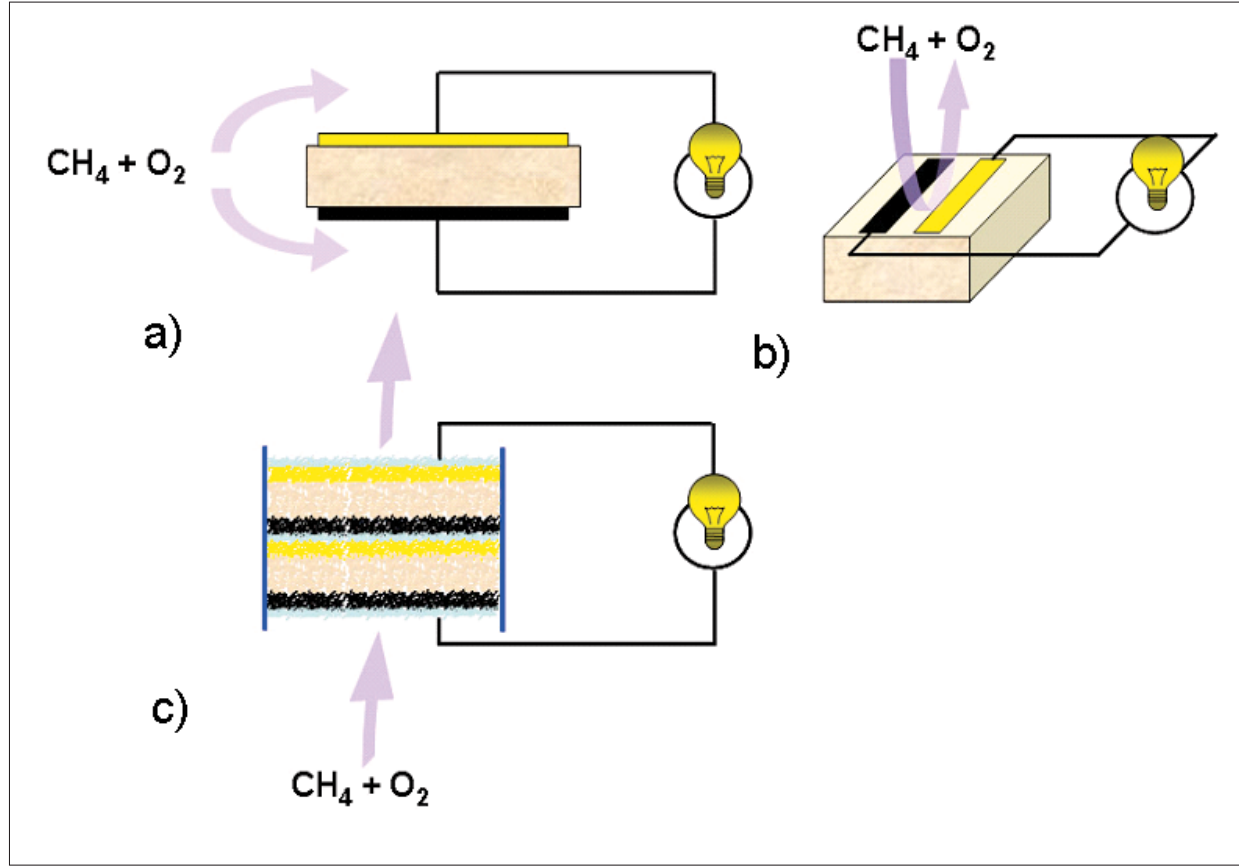

Fig. 7. Possible designs for SC-SOFCs. a) classic sandwich design, b) side by side c) fully porous

ic properties. One is active for the reduction of oxygen and the other for the activation of the fuel, i.e. adsorption and dissociation of hydrogen from a mixture of hydrogen and air. Van Gool suggested the use of gold or silver as the cathode material (stable oxide, unstable hydride) and platinum, palladium or iridium as the anode (stable hydride, unstable oxide). In 1990 Dyer was able to generate electrical power from a device with electrodes made of platinum separated by a thin, ion conducting and porous film [11]. Fig. 6 schematically shows the design of the electrochemical device and the used materials. A voltage of approximately $1 \mathrm{~V}$ was achieved at room temperature on a mixture of hydrogen and air. The achieved power density was in the range of 1 to $5 \mathrm{~mW} / \mathrm{cm}^{2}$.

Hibino and Iwahara have been working on SC-SOFCs in recent years. The first cells had similar power densities to the cells described by Dyer, i.e. in the range of 2-5 $\mathrm{mW} / \mathrm{cm}^{2}$ [12]. With very similar materials Gödickemeier et al. proved the feasibility of connecting individual cells on one electrolyte plate in series without the need for having sealed gas compartments for each cell [13]. Thus, with one element consisting of series connected cells it is possible to obtain useful voltages higher than only $1 \mathrm{~V}$.

Hibino et al. also used alternative electrolyte materials, e.g. $\mathrm{La}_{0.9} \mathrm{Sr}_{0.1} \mathrm{Ga}_{0.8} \mathrm{Mg}_{0.2}$ $\mathrm{O}_{3-\delta}$ (LSGM), which showed better performance than YSZ [14]. This was mainly due to the higher ionic conductivity of the utilized materials. Ceria $\left(\mathrm{CeO}_{2}\right)$ based SCSOFCs showed maximum power densities of $644 \mathrm{~mW} / \mathrm{cm}^{2}$ at $550{ }^{\circ} \mathrm{C}$ and $269 \mathrm{~mW} / \mathrm{cm}^{2}$ at $450{ }^{\circ} \mathrm{C}$ [15] with a fuel utilization that was estimated to be around $10 \%$.
An advantage of the Single Chamber approach is that completely new designs can be envisaged such as illustrated in Fig. 7. For research and development the classic design (a) appears to be most feasible because of simple geometry and easy fabrication procedures. The 'side by side' design shown in (b) allows easy interconnection of cells located on the same side of an electrolyte substrate. Very thin layers of active components can be used and this reduces the material costs as well as increases the specific power density [14]. The feasibility of the side by side design and the optimum geometry have recently been evaluated for the case of mixed reactant direct methanol fuel cells [16]. In the case of SC-SOFCs gas leaks in the electrolyte are of no concern. The fully porous design shown in Fig. 7(c) makes use of the absent constriction of a gas tight electrolyte. The concept of fully porous fuel cells has been proposed for direct methanol fuel cells [17] and can easily be adopted for SOFCs.

\section{Electrolyte}

\subsection{Oxygen Ion Conducting Electrolytes}

Solid oxide fuel cell (SOFC) electrolyte materials should have high ionic conductivity and low electronic conductivity. The available electrolyte materials differ mainly in the nature of their conductivity either having purely ionic or mixed ionic electronic conductivity (MIEC). The ionic conductivity of an electrolyte can be enhanced by introducing acceptor dopants and consequently oxygen vacancies [18]. YSZ is the state-of-the-art electrolyte for SOFCs. These solid solutions are primarily ionic conductors and show nearly no electronic conductivity. They have to be operated at high temperatures, around $800-1000{ }^{\circ} \mathrm{C}$ [19].

The amount of oxygen vacancies and consequently ionic conductivity is increased by the introduction of the trivalent yttria dopants into the zirconia lattice [20-22]. This stabilizes the cubic phase at $\mathrm{Y}_{2} \mathrm{O}_{3}$ contents of $8 \mathrm{~mol} \%$. The tetragonal form $\left(3 \mathrm{~mol} \% \mathrm{Y}_{2} \mathrm{O}_{3}\right)$ shows time-dependent degradation [21][23-25] because water is produced at the anode which leads to hydrothermally assisted transformation of the tetragonal to the monoclinic phase [26].

On the cathode side, YSZ is in contact with $\mathrm{LaCoO}_{3}$ or $\mathrm{LaMnO}_{3}$ based cathode materials. At high operating temperatures of 800 to $1000{ }^{\circ} \mathrm{C}$ both materials react forming insulating $\mathrm{La}_{7} \mathrm{Zr}_{2} \mathrm{O}_{7}$ which leads to a gradual increase of cathode overpotential [27-29]. It has been recognized that for smaller SOFC stacks the operating temperature should be lowered without increasing the internal resistance of the cell [30-33]. In the following, alternative materials to stateof-the-art YSZ such as scandia-doped zirconia, doped ceria solid solutions, bismuthbased oxides or lanthanum gallate based electrolytes are discussed [34][35]. In Fig. 8 the ionic conductivity of these electrolyte materials are plotted as a function of temperature [36][37]. It has been well known since the 1970s that Sc-stabilized zirconia (ScSZ) shows the highest ionic conductivity of all zirconia solid solutions. The reason for this is the smallest tendency for vacancy cluster formation with increasing dopant concentration due to the close match of the $\mathrm{Sc}^{3+}$ ionic radius with the $\mathrm{Zr}^{4+}$ host cation [38-40]. However, Sc-doped zirconia becomes unstable especially at intermediate temperatures [41]. Politova and Irvine recently investigated the possibility of ScSZ stabilization by yttria doping. Small additions of yttria considerably stabilized the cubic phase of ScSZ at the prospective fuel cell operating temperature. However, it was not possible to overcome the time-dependent degradation of the conductivity during long annealing periods [42].

Ceria $\left(\mathrm{CeO}_{2}\right)$ based electrolytes offer an ionic conductivity up to 4-5 times higher than that of zirconia solid solutions in the intermediate and low temperature regime [43]. Doping of ceria with e.g. $\mathrm{Gd}_{2} \mathrm{O}_{3}$, $\mathrm{Y}_{2} \mathrm{O}_{3}, \mathrm{CaO}$ or $\mathrm{Sm}_{2} \mathrm{O}_{3}$ introduces oxygen vacancies and induces ionic conductivity [44]. The development of these materials for intermediate temperature SOFCs has been extensively reviewed by Steele [45]. $\mathrm{Sm}_{2} \mathrm{O}_{3}$ doped ceria (CSO) and $\mathrm{Gd}_{2} \mathrm{O}_{3}$ doped ceria (CGO) exhibit the highest conductivities of all rare earth doped $\mathrm{CeO}_{2}$ sol- 
id solutions [46]. Again, it is assumed that this is due to the ionic radii of $\mathrm{Sm}^{3+}$ and $\mathrm{Gd}^{3+}$ which nearly match the ionic radius of $\mathrm{Ce}^{4+}$ [46-49]. Furthermore, these compounds show the lowest electronic conduction at low oxygen partial pressures. At 700 ${ }^{\circ} \mathrm{C}$ the conductivity of $\mathrm{CGO}$ and $\mathrm{CSO}$ (both with 10-25\% dopant) come close to the conductivity of YSZ at $1000{ }^{\circ} \mathrm{C}$ [50][51]. A monotonic increase of ionic conductivity is observed with increasing $\mathrm{Sm}_{2} \mathrm{O}_{3}$ or $\mathrm{Gd}_{2} \mathrm{O}_{3}$ content until a maximum is reached. The oxygen vacancies then begin to form defect clusters with the doped cations (e.g. $\mathrm{Sm}^{\prime}{ }_{\mathrm{Ce}} \mathrm{V}_{\ddot{\mathrm{O}}}$ ) which will decrease the mobility of the oxygen vacancies [52]. As ceria becomes reduced under low oxygen partial pressures at the anode-electrolyte interface the material exhibits n-type electronic conductivity [53] especially at higher operation temperatures. Therefore ceria solid solutions are recommended for operation temperatures below $800{ }^{\circ} \mathrm{C}$ where excellent SOFC performance can be obtained [54] or in combination with YSZ layers blocking electronic conduction.

In contrast to zirconia-based electrolytes, ceria solid solutions exhibit lower cathode-electrolyte overpotentials [55-57]. Doshi et al. measured a high power output at $500{ }^{\circ} \mathrm{C}$ of a fuel cell with $\mathrm{CGO}$ electrolyte, lanthanum cobalt based cathode and a Ni-CGO anode [54]. CGO elec- trolytes are superior to YSZ for low temperature SOFCs because at low temperatures $\mathrm{CGO}$ behaves as a pure ionic conductor with much higher ionic conductivity. Several authors proposed doped ceria electrolytes for intermediate and low temperature fuel cell operation [19][53][54][58].

Dikmen et al. investigated the influence of high ionic conductive bismuth oxide as a dopant in ceria. The authors report higher ionic conductivities due to the bismuth oxide doping compared to gadolinia doping of ceria. However, it remains unclear how chemically stable this electrolyte is to reducing atmospheres and phase transitions of bismuth oxide [59].

The highest ionic conductivities at 300-700 ${ }^{\circ} \mathrm{C}$ are found in $\mathrm{Bi}_{2} \mathrm{O}_{3}$-based electrolytes like BIMEVOX (Fig. 8) [60][61]. For temperatures as low as $300{ }^{\circ} \mathrm{C}$ BIMEVOX electrolytes show conductivities as high as YSZ at $800{ }^{\circ} \mathrm{C}$ [62]. BIMEVOX are bismuth vanadium oxides $\mathrm{Bi}_{4} \mathrm{~V}_{2} \mathrm{O}_{11}$ where the vanadium is partially substituted to yield $\mathrm{Bi}_{2} \mathrm{~V}_{1-\mathrm{x}} \mathrm{Me}_{\mathrm{x}} \mathrm{O}_{\mathrm{y}}$ solid solutions [63]. The BIMEVOX family of materials exhibits specific properties as electrolytes as well as oxygen electrodes. The high oxide anion diffusion observed at moderate temperature results from the synergy between the highly polarisable ion pair of the BiIII cation in the vicinity of the $\mathrm{V}-\mathrm{O}$ diffusion slab on the one hand, and the flex-

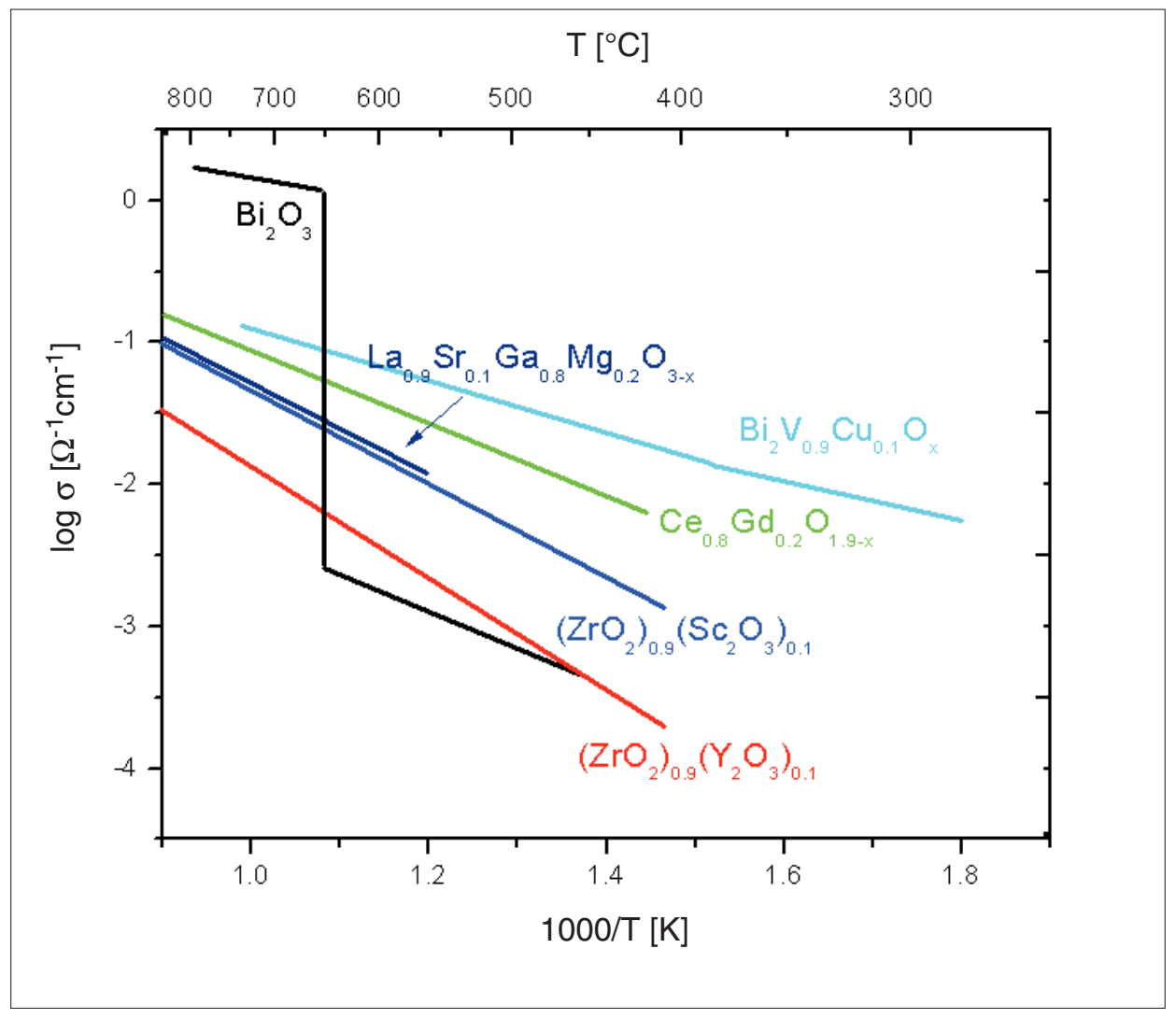

Fig. 8. Ionic conductivities of different electrolyte materials [36][37] ibility of this $\mathrm{V}-\mathrm{O}$ network on the other hand. Moreover, the same material is able, under imposed polarisation, to self convert reversibly and dynamically from electrolyte to electrode. All these specific characteristics led to a new concept of ceramic oxygen generator based on a unique material [64]. However, the main drawback of BIMEVOX electrolytes is that they slowly decompose at SOFC operating temperatures. Reviews on stability and ionic conductivity of $\mathrm{Bi}_{2} \mathrm{O}_{3}$-based electrolytes are given by Shuk et al. [37] and Sammes et al. [65].

Doped lanthanum gallates $\left(\mathrm{LaGaO}_{3}\right)$ are currently attracting considerable attention as promising electrolytes for intermediate temperature SOFC applications. When the trivalent lanthanum and gallium are doped with divalent cations like $\mathrm{Sr}$ and $\mathrm{Mg}$ forming $\mathrm{La}_{1-\mathrm{x}} \mathrm{Sr}_{\mathrm{x}} \mathrm{Ga}_{1-\mathrm{y}} \mathrm{Mg}_{\mathrm{y}} \mathrm{O}_{3-\mathrm{x} / 2-\mathrm{y} / 2}$ (LSGM) the ionic conductivity is significantly higher than that of YSZ but still lower than that of CGO [66]. The stability seems to be higher than that of CGO and thus, it seems attractive to use LSGM electrolytes at temperatures of $600-800{ }^{\circ} \mathrm{C}$ [67]. However, it is difficult to produce single phase LSGM since secondary phases such as $\mathrm{La}_{4} \mathrm{Ga}_{2} \mathrm{O}_{9}$ and $\mathrm{SrLaGa}_{3} \mathrm{O}_{7}$ prevail at grain boundaries reducing the conductivity [68]. Furthermore Weitkamp and coworkers report a limited stability of LSGM under reducing and oxidizing conditions followed by the development of n-type conductivity at low and p-type at high oxygen partial pressures [69].

Increased power densities and/or reduced operation temperatures can also be achieved with reducing the thickness of the electrolytes and thereby reducing the ohmic losses. In many concepts of flat bipolar cells, the electrolyte thickness is in the order of 100 to $300 \mu \mathrm{m}$ and serves also as the structural load bearing component. When reducing the thickness of the electrolyte to the range of $\mu \mathrm{m}$ or even to several hundred nanometres, the anode or the cathode is used as support structure. Good power densities in SOFCs have been obtained with thin YSZ electrolytes prepared by colloidal methods by Will et al. [70]. Electrophoretic deposition of fine YSZ particles dispersed and stabilized in water was used to produce $20 \mu \mathrm{m}$ thin electrolytes that resulted in power densities of more than 200 $\mathrm{mW} / \mathrm{cm}^{2}$ at reduced operating temperatures of $700{ }^{\circ} \mathrm{C}$.

Other methods have been reported concerning the development of thin-film processes for SOFC applications such as electrochemical vapour deposition [71], plasma spraying [72], physical vapour deposition [73] and pyrolysis of dip coated or sprayed metal salt solutions [74][75].

Although some of these physical and chemical methods produce dense layers, 
they are less suitable for mass production except spray deposition. Perednis et al. obtained more than $600 \mathrm{~mW} / \mathrm{cm}^{2}$ at $700{ }^{\circ} \mathrm{C}$ with anode supported cells with bi- and trilayer electrolytes as thin as $300 \mathrm{~nm}$ based on ceria as shown in Fig. 9 [76][77].

Bilayer electrolytes can combine advantages of two electrolytes. In case of a ceria/zirconia based bilayer, ceria is used at the cathode side being in thermodynamic equilibrium with lanthanum strontium iron perovskite avoiding the $\mathrm{La}_{7} \mathrm{Zr}_{2} \mathrm{O}_{7}$ formation which degrades the cell when zirconia is combined with these cathodes. On the other side, when using zirconia on the anode side, the ceria-based electrolyte is protected against reduction and electronic conductivity is avoided in the electrolyte [77-81]. The different electrolyte materials suitable for SOFCs have been extensively reviewed elsewhere [1][18][19][31][34] [67][68][82-84].

\subsection{Proton Conducting Electrolytes}

Various ceramic materials exhibit protonic conductivity at moderate temperatures. By replacing the oxygen ion conductive electrolyte in a SOFC with a proton conductor, several improvements regarding the fuel cell performance can be envisaged. The first studies in the field of protonic conductivity and its application to SOFCs were conducted by Iwahara et al. for $\mathrm{SrCeO}_{3}$-based materials [85]. The highest proton conductivities have been reported for perovskites $\left(\mathrm{ABO}_{3}\right)$ such as $\mathrm{BaCeO}_{3}$-based materials [86-90]. Proton conductivity is achieved by the partial substitution of the B site cation with an acceptor dopant ion which is charge compensated by oxygen vacancies. Trivalent dopants have been demonstrated to be more effective than bivalent ones due to their higher protonic defect concentration and mobility [91]. Most $\mathrm{BaCeO}_{3}$-based materials display protonic conduction at intermediate temperatures and become oxygen ion conductors at higher temperatures, see e.g. [87]. The atmosphere can also influence the conduction mechanism. Typical conductivities are between 0.1 to $0.001 \mathrm{~S} / \mathrm{cm}$ for temperatures from 1000 to $600{ }^{\circ} \mathrm{C}$ [90]. A comparison of the proton conductivities for various oxides is given elsewhere [92]. $\mathrm{BaCeO}_{3}$ based materials possess the highest molar volume and the deviation from the ideal cubic perovskite structure is small [93]. These properties are assumed to be necessary prerequisites for a material to exhibit high protonic conductivity [92]. However, these materials usually lack sufficient thermodynamic stability. Cerates, for example, form carbonates in air [94] as well as in $\mathrm{CO}_{2}$-containing atmospheres [95]. A number of investigations have therefore been conducted in the last years with the aim to combine high proton conductivity with improved thermodynamic stability.

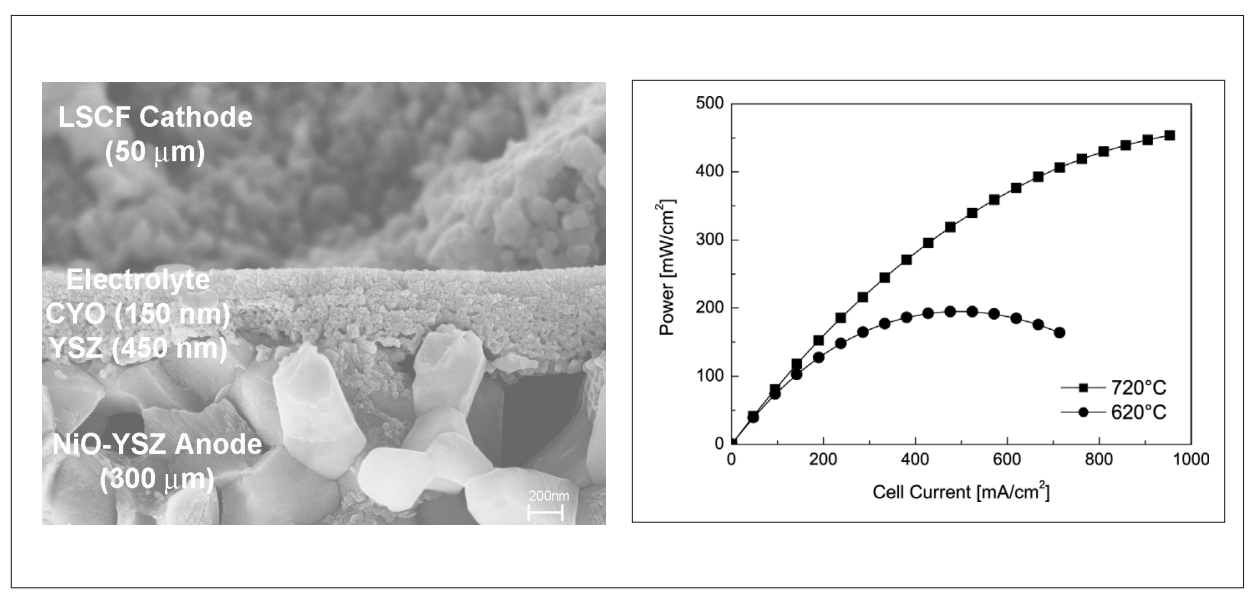

Fig. 9. Thin-film SOFC with bi-layer YSZ/CGO electrolyte and power output at 620 and $720{ }^{\circ} \mathrm{C}[76][77]$

Zirconates, such as Y-doped $\mathrm{BaZrO}_{3}$, offer high proton conductivity with the necessary thermodynamic stability for fuel cell applications [94][96]. By doping $\mathrm{BaZrO}_{3}$ with $15-20 \mathrm{~mol} \%$ of yttrium, proton conductivities were found to be higher than the conductivities of the best oxygen ionic conductors [97]. Even for high dopant levels, the proton mobility is not changed, making Y-doped $\mathrm{BaZrO}_{3}$ a suitable candidate as electrolyte material [92]. Appreciable proton conduction in hydrogen containing atmospheres and p-type conductivity for high oxygen partial pressures have also been investigated for divalent doped scandates like $\mathrm{LaSc}_{1-\mathrm{x}} \mathrm{Mg}_{\mathrm{x}} \mathrm{O}_{3-\delta}$ [98]. Acceptor-doped Sr$\mathrm{TiO}_{3}$ also showed protonic conductivity combined with a high thermodynamic stability although the protonic defect formation is less favoured compared to acceptordoped $\mathrm{BaZrO}_{3}$ [97].

In order to form proton defects, water vapour is incorporated into the crystal lattice of the proton conductor according to Eqn. 1:

$$
H_{2} \mathrm{O}+V_{O}^{\bullet \bullet}+\mathrm{O}_{O}^{x} \leftrightarrow 2 O H_{O}^{\bullet}
$$

The positively charged protonic defect forms a covalent bond with oxygen of the lattice. If the concentration of protonated oxygen atoms is sufficiently high, a protonic current flows across the electrolyte. The protons are then supplied on the anode side:

$$
H_{a d s}+\mathrm{O}_{O}^{x} \rightarrow \mathrm{OH}_{O}^{\bullet}+e^{\prime}
$$

After crossing the electrolyte, the defects are removed by:

$$
2 \mathrm{OH}_{\mathrm{O}}^{\bullet}+\frac{1}{2} \mathrm{O}_{2}(\mathrm{~g})+2 e^{\prime} \rightarrow \mathrm{H}_{2} \mathrm{O}_{a d s}+2 \mathrm{O}_{\mathrm{O}}^{x}
$$

The diffusion of the protonic defects across the electrolyte material requires a counter flux of oxygen vacancies in order to maintain charge neutrality. This counterdiffusion represents one of the main advantages of proton conductors for fuel cells, the ambipolar steam permeation [99]. Since the incorporation of water vapour according to Eqn. (1) is reversible and independent of reactions (2) and (3), proton conduction will take place due to any steam concentration gradient. Typical values of activation energies for proton conduction are around 0.5 $\mathrm{eV}$ [100]. If an external load is applied, hydrogen will be incorporated into the electrolyte according to Eqn. (2) and steam will be produced on the cathode side according to Eqn. (3) as shown in Fig. 10. Consequently, the steam partial pressure will increase on the cathode side, so that some of the steam will react according to Eqn. (1) and return back to the anode. Therefore, the Faradaic current of the cell is independent of the steam permeation and only depends on the concentration and mobility of the protonic defects [99]. If the cell is operated with hydrocarbons, coking cannot take place at the anode side as long as the diffusion of water through the electrolyte keeps up with the adsorption and decomposition of the fuel. Furthermore, water vapour is produced at the cathode side and thus cannot dilute the fuel [99].

Typically achieved maximum power outputs of cerate- as well zirconate-based cells are around $20 \mathrm{~mW} / \mathrm{cm}^{2}$ [92][99]. Further research on proton conducting materials is therefore needed to make proton conductor based cells to serious competitors for fuel cells based on oxygen conductors.

\section{Anode}

The main functionality of a SOFC anode is to provide electrochemically active 


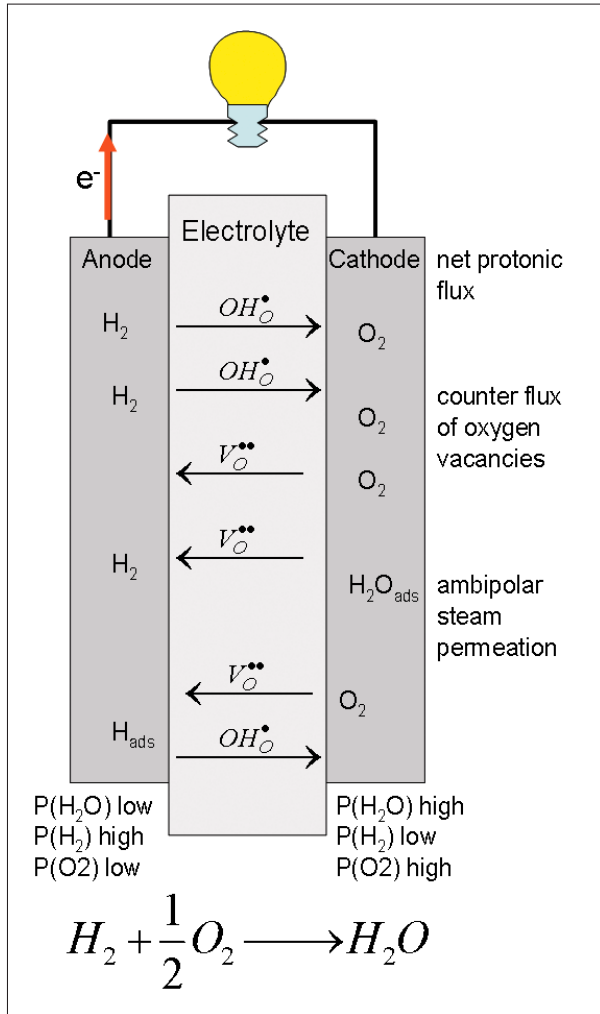

Fig. 10. Schematic drawing of a fuel cell with proton-conducting electrolyte

reaction sites for the oxidation of the fuel gas molecules and to transport electrons from the oxidation reaction to connecting cell components. Many factors determine the materials choice for the anode. Anodes provide pathways for the fuel to reach the reaction sites and for the reactants to diffuse away from the reaction sites: They also require a high electronic conductivity for current transport and should be chemically compatible to adjacent cell components such as the electrolyte, current collector, and structural elements. Specifically when used in anode supported fuel cells, they also have to be structurally stable over an adequate lifetime.

In the early development of SOFC, noble metals such as ruthenium, rhodium, palladium, silver, platinum and gold and from the transition metal group manganese, iron, cobalt, nickel and copper were considered [101]. Platinum is a good electrocatalyst although the high vapour pressure of platinum sub-oxides prevents its use in SOFC operating between 900 and $1000{ }^{\circ} \mathrm{C}$. Gold shows almost no catalytic activity and poor adhesion to oxides. From the transition metal oxides, nickel proved to be the best choice in terms of catalytic activity and redox stability. However, the pure metal has a strong tendency towards grain growth at elevated temperatures and a significantly different thermal expansion coefficient than commonly used electrolyte materials.
Therefore, nickel is combined with a ceramic compound, such as zirconia or ceria, forming three interconnected frameworks of metal, ceramic and pores. This cermet becomes a good metallic conductor for nickel contents above the percolation threshold. In the past, research has been mainly focused on yttria-stabilized zirconia (YSZ) as ceramic material for electrolytes and in cermets for anodes for its good structural stability, good electrical conductivity at high temperatures and stability under all atmospheric conditions.

In a purely ionic conductor like YSZ the oxidation of the fuel gas with oxygen ions coming from the cathode side through the electrolyte is believed to occur only in the triple phase boundary $(t p b)$, the connecting points of metal, ceramic and pore. The ceramic network not only provides structural integrity and hinders the trapped nickel particles from excessive grain growth but also provides a pathway for oxygen ions, effectively extending the triple phase boundary from the flat electrolyte interface into the anode structure.

Nickel-YSZ anodes have been thoroughly investigated for the use with hydrogen in terms of manufacturing, raw materials selection and microstructural properties. Anodes based on Ni-YSZ cermets have been steadily improved through ceramic processing, e.g. careful selection of raw materials [102], adjustment of particle sizes [103] and grading of nickel content in the structure [104] in the last few years. Some of these materials optimizations are reported in [105-108] and some in a more general context [36][68][84][109-111]. Möbius recently reviewed the history of solid electrolyte fuel cells and especially the anodes herein [112].

One of the most promising new materials for intermediate temperatures is doped ceria, a mixed ionic electronic conductor, which has found considerable attention as electrolyte [44]. As ceria becomes reduced at the anode side of the fuel cell and thereby an n-type semiconductor it can be assumed that the triple phase boundary is no longer defined by single connecting points of pore, metal and ceramic but is enlarged to the surface of all ceramic grains in the microstructure. Ni-CGO anodes have been successfully fabricated and excellent performances have been reported in hydrogen as fuel at intermediate temperatures [113-115]. Additions of doped ceria can also be used to increase the performance of conventional Ni-YSZ composites [116][117].

One advantage of SOFCs as compared to PEM or MCFC is their potential to be operated directly on hydrocarbon or alcohol fuels without complex fuel processing [67]. More exotic fuels include $\mathrm{CH}_{3} \mathrm{OCH}_{3}$ [118], wood gasification gases [119], $\mathrm{H}_{2} \mathrm{~S}$ [120],
$\mathrm{CO}$ [121] and methane [122]. Pure $\mathrm{CH}_{4}$ can either be directly electrochemically oxidized with oxygen ions at the anode or it can, as well as any other hydrocarbon, be internally or externally steam reformed with water vapour to yield carbon monoxide and hydrogen [105]. In conventional NiYSZ anodes the nickel can be used as steam reforming catalyst to form hydrogen at the anode. Water can either originate from an external source through the humidification of the fuel gas to obtain large steam to carbon ratios or in parts from water produced by the fuel oxidation reaction. Methane at high steam to carbon ratios can be reformed without carbon deposits on nickel containing anodes but the excellent steam reforming properties of Ni leads to a total conversion within the first few millimetres of the fuel inlet resulting in steep thermal gradients within the cell due to the endothermic character of the reaction.

The major problem associated with the use of dry methane or higher hydrocarbons for the direct oxidation is the formation of carbon deposits in the form of filamentous carbon, tar, and soot during operation at high temperatures. This is due to the high catalytic activity of metallic nickel towards carbon formation, rapidly clogging the pores and blocking reaction sites on the nickel surface [123][124]. Even at low carbon levels the reaction of $\mathrm{Ni}$ with carbon will finally lead to a disintegration of the anode by a process called metal dusting [125]. Takeguchi et al. [126] added small amounts of precious metals to conventional $\mathrm{Ni}$-YSZ cermets to shift the active sites for steam reforming from $\mathrm{Ni}$ to the noble metal and observed less carbon deposits with $\mathrm{Ru}$ and $\mathrm{Pt}$ during steam reforming of methane.

Another problem at the anode associated with the use of natural gas based fuels is poisoning by adsorption of traces of $\mathrm{H}_{2} \mathrm{~S}$ usually present in any natural fuel on the nickel surface [127]. Dilution of the fuel gas by steam reforming products and oxidized fuel such as carbon dioxide and water vapour can result in performance loss at high fuel utilization [128] or even reoxidation of metallic nickel to nickel oxide near the fuel outlet.

The search for alternative anodes with lower activity for cracking of hydrocarbons and better stability than pure Nickel has proceeded in various directions. The catalytic activity of nickel itself can be gradually reduced by alloying the metal with other elements, e.g. gold [129] or copper [130-132].

Copper, similar to gold, exhibits almost no electrochemical activity and the complete replacement of $\mathrm{Ni}$ by $\mathrm{Cu}$ to form a cermet with ceria leads to an anode with the copper being a purely electronically conducting current collector and the ceramic 
being the actual electrochemically active component [133].

Pure and doped ceria are known for their good performance as oxidation catalysts or as catalyst supports. CGO $\left(\mathrm{Ce}_{0.9} \mathrm{Gd}_{0.1} \mathrm{O}_{2-\delta}\right)$ was found to have almost no tendency towards carbon formation [134][135] but exhibits a rather low catalytic activity for steam reforming and cracking of methane at $1000{ }^{\circ} \mathrm{C}$. The results of Marina et al. [136][137] for increased gadolinia dopant levels in $\mathrm{Ce}_{0.6} \mathrm{Gd}_{0.4} \mathrm{O}_{2-\delta}$ /gold cells are consistent with these findings. Zhao and Gorte. [138] examined the catalytic activity of various doped cerium oxides for the direct n-butane oxidation and reported that pure $\mathrm{CeO}_{2}$ always outperforms doped samples and that increasing dopant levels reduce reaction rates. The catalytic oxidation of methane has been recently addressed by Horita $e t$ al. [139] using the isotope labelling technique to identify reaction sites on YSZ and yttriadoped ceria (YDC) with gold and nickel electrodes. The YDC substrate proved to be efficient in reducing carbon deposits on $\mathrm{Ni}$ by increasing the oxygen concentration on the Ni surface through proton interaction between $\mathrm{Ni}$ and YDC.

Gorte and co-workers [140][141] as well as other groups have fabricated and tested $\mathrm{Cu}$-pure/doped ceria anodes for the direct oxidation of methane and higher hydrocarbons. However, their spectacular interpretations of the activity of $\mathrm{Cu}$ to process propane had to be corrected. The power output of $\mathrm{Cu}$-pure/doped ceria anodes containing fuel cells was solely due to $\mathrm{H}_{2}$ as fuel originating from thermal decomposition of propane to propene occurring at $700{ }^{\circ} \mathrm{C}$ also in absence of $\mathrm{Cu}$ as recently shown by Jörger [142].

Copper-containing anodes are also believed to be more tolerant against sulphur than nickel-based electrodes [140]. The steam reforming capabilities of $\mathrm{Cu}-\mathrm{CGO}$ cermets can be further enhanced by the addition of small amounts of noble metals such as Ru [143][144].

Irvine and co-workers [105][145][146] investigated the mixed ionic electronic conductor titania-doped YSZ (YTZ) and YTZ with yttrium substituted by scandium [147] and compared it to ceria. The thermal, mechanical and electrical properties of YTZ in a fuel cell environment seem to be favourable [148]. The pure form [149] as well as $\mathrm{Ni}[150]$ and $\mathrm{Cu}$ [151] cermets performed well in hydrogen. YTZ was found not to promote methane cracking [152] but was catalytically less active than ceria and showed only limited electronic conductivity.

Efforts have been made to replace the traditional cermet anode by a pure ceramic material [153] for the direct utilization of natural gas as fuel. Perovskites, fluorites, pyrochlores and tungsten bronzes [146][154-158] were investigated. Rutile structures such as $\mathrm{Nb}_{2} \mathrm{TiO}_{6}$ show a high electronic conductivity, especially under reducing atmospheres but have very low thermal expansion coefficients compared to standard fuel cell materials [159]. Reich et al. [160] related the poor electrochemical performance of niobates to the slow ionic diffusion in the material and proposed to use it as a current collector instead of an anode. Tungsten bronzes showed either poor stability under hydrogen, too large thermal expansion coefficient mismatch to the electrolyte or poor electrochemical performance [161-163].

Amongst the more promising candidates to replace established anodes are lanthanum strontium chromite $\mathrm{La}_{1-\mathrm{x}} \mathrm{Sr}_{\mathrm{x}} \mathrm{CrO}_{3}$ (LSC) perovskites [164]. This class of material is already used as interconnect in SOFC stacks and shows good stability under operating conditions [165]. Vernoux et al. [166] reported stable electrochemical behaviour of B-site vanadium-doped LSC. Sfeir et al. [167][168] investigated the catalytic activity of various $\mathrm{A}$ and $\mathrm{B}$ site dopants of $\mathrm{LaCrO}_{3}$ and found $\mathrm{Sr}$ and $\mathrm{Ni}$ to be the most suitable substituents for anode purposes, although it is not clear whether the exsolution of $\mathrm{Ni}$ from the structure led to the good performance. Sauvet et al. [169][170] tried to improve reforming activity by small ruthenium additions to $\mathrm{La}_{1-\mathrm{x}} \mathrm{Sr}_{\mathrm{x}} \mathrm{CrO}_{3}$. Gonzales-Cuenca et al. [171] tested lanthanum-based chromite-titanate perovskites and found insufficient electronic conductivity. Interesting results have also been obtained with lanthanum strontium titanates [172][173]. Hui and Petric [174-176] reported the properties of rare-earth-doped $\mathrm{SrTiO}_{3}$ and propose yttrium doping for further investigations. Slater et al. [177] reported conductivity data on A-site deficient $\mathrm{Sr}_{1-3 \times / 2} \mathrm{La}_{\mathrm{x}} \mathrm{TiO}_{3-\delta}$.

Based on the experience with lanthanum strontium chromites Tao and Irvine [178] investigated complex perovskites of the structure $(\mathrm{La}, \mathrm{Sr})_{2} \mathrm{M}_{1-\mathrm{x}} \mathrm{Cr}_{1+\mathrm{x}} \mathrm{O}_{6-\delta}$ with transition metals $\mathrm{M}$ on the B-sites. Excellent electrochemical performance comparable to that of Ni-YSZ and material stability in hydrogen and dry methane were achieved with high levels $(\mathrm{x}=0.5)$ of Mn doping.

The requirements for an efficient fuel electrode are many and some of the new materials show very promising properties for the development of next generation anodes that will enable the use of available fuels and operate at lower temperatures than existing ones.

\section{Cathode}

For proper function as a cathode in a solid oxide fuel cell, the material should have a high electrocatalytic activity towards oxygen reduction and a high chemical stability in an oxidizing environment without forming highly resistive reaction products with the electrolyte and current collector [179][180]. The material should exhibit similar thermomechanical properties as the electrolyte to avoid stresses developing upon heating and cooling [181] and it should have high electrical conductivity.

Most reviews on SOFCs deal with stateof-the-art cathode materials such as $\mathrm{La}_{1-x}$ $\mathrm{Sr}_{\mathrm{x}} \mathrm{MnO}_{3-\delta} \quad(\mathrm{LSM})$ and $\mathrm{La}_{1-\mathrm{x}} \mathrm{Sr}_{\mathrm{x}} \mathrm{Co}_{1-\mathrm{y}}$

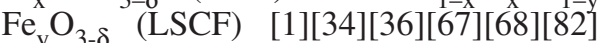
[84][110][182-186]. A few of these reviews also include emerging materials [19][68][84][184]. The following will be limited to cathode material aspects and exclude most processing related techniques which can be found elsewhere [187].

The oxygen reduction reaction at the interface between a SOFC cathode and an $\mathrm{O}^{2-}$ conducting electrolyte is:

$$
O_{2}(\text { gas })+2 V_{o}^{*}+4 e^{-} \leftrightarrow 2 O_{o}^{x}
$$

and is schematically represented in Fig. 11. SOFC cathodes are usually p-type semi-conductors [188][189] that can be either an electronic or mixed ionic-electronic conductor (MIEC). Reduction of the electrokinetic losses and optimization of the electrode performance are two major goals of research and development. In case of pure electronic conductors, the oxygen adsorbs on the surface of the material and diffuses over its surface towards the $t p b$ where it becomes charged and incorporated in the electrolyte. The electrode acts as an electron supplier. Accordingly, improving the cathode performance towards high current density and low overpotentials is closely related to the increase of the $t p b$ length.

If the SOFC cathode is a MIEC, oxygen can be reduced on the surface and diffuse through the bulk of the electrode. Consequently surface and bulk pathways that coexist in parallel are in competition and the fastest one determines the kinetics of the overall reaction. If the surface pathway is rate-determining, the electrode exhibits a similar behaviour as for a purely electronic conductor, as described previously. On the other hand, if the oxygen migrates mainly through the bulk of the cathode, the electrochemical reaction is promoted by producing dense thin layers, enhancing thereby oxygen exchange at both the MIEC/gas and MIEC/electrolyte interfaces. These materials should have a high oxygen exchange capacity for an easy incorporation of oxygen in their lattice and high oxygen diffusivity for high transport rates. However, the mechanism and kinetics of oxygen reduction at SOFC cathodes are still under ques- 


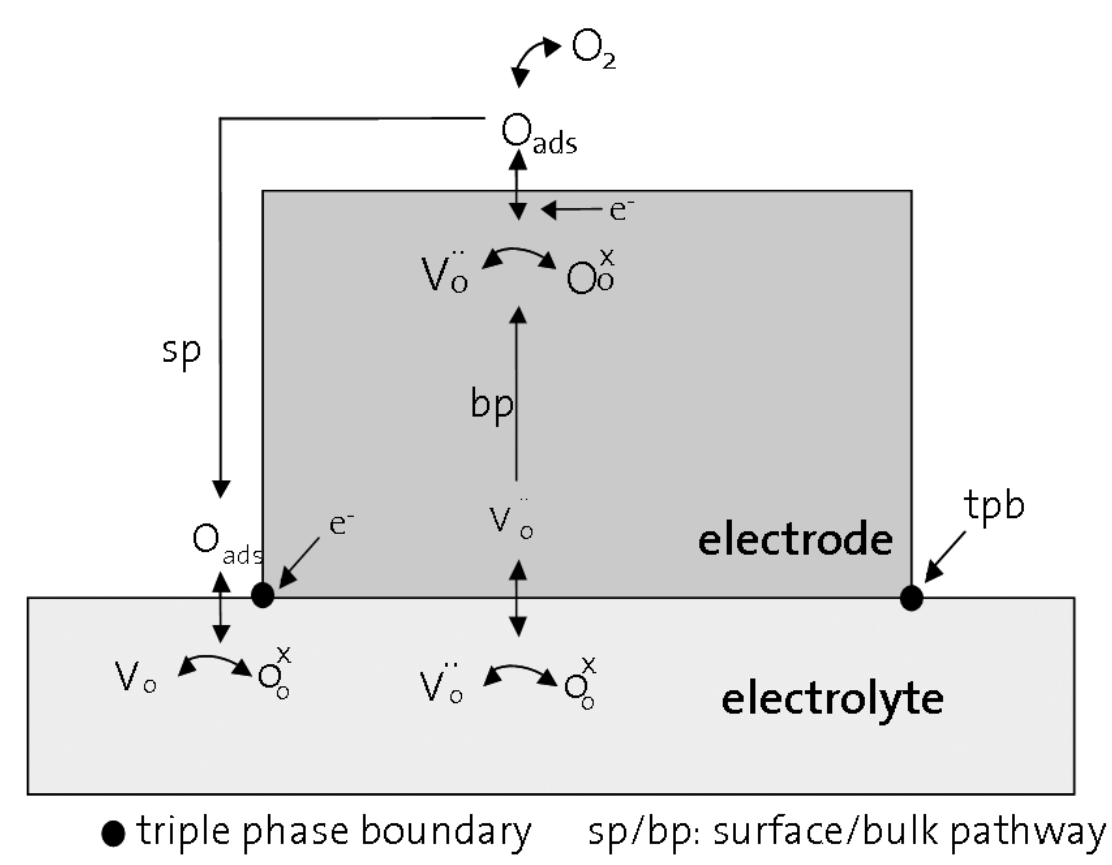

Fig. 11. Schematic representation of oxygen reduction in a mixed ionic-electronic conductor: Surface and bulk reaction pathways are parallel and in competition. On the surface pathway, charge transfer occurs at the triple phase boundary.

tion. The interaction between oxygen and the MIEC and oxygen diffusion have been subject to numerous studies [190-192]. Comprehensive understanding and modelling of these reaction mechanisms constitute an ongoing field of investigations, from which controversial results were published so far [193-197].

\section{1. $\mathrm{La}_{1-\mathrm{x}} \mathrm{Sr}_{x} \mathrm{MnO}_{3-x / 2}$ (LSM) and $\mathrm{La} \mathrm{Sr}_{1-X} \mathrm{Co}_{y} \mathrm{Fe}_{1-y} \mathrm{O}_{3}$ (LSCF)
Cathodes}

The choice of cathode materials is rather limited: Noble metals such as Pt are suitable, but exhibit prohibitive costs for SOFC application at higher temperatures due to high $\mathrm{Pt}$ suboxide vapour pressure. $\mathrm{La}_{1-\mathrm{x}} \mathrm{Sr}_{\mathrm{x}} \mathrm{MnO}_{3-\mathrm{x} / 2}$ (LSM), as the state-ofthe-art electronic conducting material, is widely used since it fulfills most of the requirements listed above; its properties are given in Table 3 with the data taken from references [181][198-200]. Usually LSM is used for the cathode when YSZ is used as the electrolyte, because the thermal expansion coefficients match well [201]. However, the rather high operating temperatures of the SOFC around 900 to $1000{ }^{\circ} \mathrm{C}$ promote degradation of the cathode and the formation of undesired resistive reaction products, such as $\mathrm{La}_{2} \mathrm{Zr}_{2} \mathrm{O}_{7}$, especially during manufacturing of LSM on YSZ [180][202-205].

Increased triple phase boundary length, better adhesion to the electrolyte and lower thermal expansion mismatch is achieved when using a LSM-YSZ composite material [204][206][207] or even composites with graded compositions [201]. Besides YSZ, CGO [208], $\mathrm{Sm}_{0.2} \mathrm{Ce}_{0.8} \mathrm{O}_{2}$ (SDC) [209] and $\mathrm{Ce}_{0.7} \mathrm{Bi}_{0.3} \mathrm{O}_{2}$ [210] are also used for fabrication of composite cathodes with LSM with improved performance.

As for most perovskite materials, the properties of LSM can be tailored by partially substituting the A and B sites of the $\mathrm{ABO}_{3}$ perovskite. The thermal expansion coefficient (TEC) can be further adjusted to that of the YSZ electrolyte by using $\left(\mathrm{La}_{1-\mathrm{x}} \mathrm{Y}_{\mathrm{x}}\right)_{0.7} \mathrm{Sr}_{0.3} \mathrm{MnO}_{3}$ [211] or $\mathrm{Sr}_{1-\mathrm{x}} \mathrm{Ce}_{\mathrm{X}} \mathrm{MnO}_{3-\delta}$ [212]. Compositions which are compatible with $\mathrm{CGO}$ as regards TEC and chemical stability are $\mathrm{Gd}_{1-\mathrm{x}} \mathrm{Sr}_{\mathrm{x}}$ $\mathrm{MnO}_{3}, \mathrm{Nd}_{1-\mathrm{x}} \mathrm{Sr}_{\mathrm{x}} \mathrm{MnO}_{3-\delta}$ [213] and $\operatorname{Pr}_{1-\mathrm{x}}$ $\mathrm{Sr}_{\mathrm{x}} \mathrm{MnO}_{3}$ [214]. The formation of reaction products between the YSZ electrolyte and the cathode can be suppressed for $\mathrm{Ln}_{1-\mathrm{x}}$ $\mathrm{Sr}_{\mathrm{x}} \mathrm{MnO}_{3} \quad(\mathrm{Ln}=\mathrm{Pr}, \mathrm{Nd})$ [215] and $\mathrm{Pr}_{1-\mathrm{x}} \mathrm{Ca}_{\mathrm{x}} \mathrm{MnO}_{3}$ [216], whereas for $\mathrm{La}_{1-\mathrm{x}} \mathrm{Ca}_{\mathrm{x}} \mathrm{MnO}_{3}$ on a $\mathrm{CaO}$-stabilized $\mathrm{ZrO}_{2}$ electrolyte no stable composition was found [217]. The conductivity can be inmaterials creased by using $\mathrm{Pr}_{0.6-\mathrm{x}} \mathrm{Sr}_{0.4} \mathrm{MnO}_{3}$ [218][219], but for substitution of Mn with Co in $\mathrm{Y}_{0.6} \mathrm{Sr}_{0.4} \mathrm{Mn}_{1-\mathrm{y}} \mathrm{Co}_{\mathrm{y}} \mathrm{O}_{3}(0 \leq \mathrm{y} \leq 0.4)$ mixtures, increasing y resulted in lower conductivity [220], the same is observed for adding $\mathrm{Al}$ to LSM [221].

The $\mathrm{La}_{1-\mathrm{x}} \mathrm{Sr}_{\mathrm{x}} \mathrm{CoO}_{3-\delta}$ (LSC) based cathodes [222-224] are typical mixed conductors offering the advantage of higher electronic and, more important, higher ionic conductivity (see Table 3). By providing this second pathway for oxygen ions, activity of the cathode is increased and lower operating temperatures are feasible. The disadvantage is that those materials react with YSZ [202][224], thus either ceria-based electrolytes or protective layers of ceria [224] or LSGM [223][225][226] on YSZ electrolytes should be used. In order to adjust the TEC of LSC-based cathodes to the one of CGO, Fe was introduced to obtain lower TEC [227]. Depending on the composition, the conductivities of $\mathrm{La}_{1-\mathrm{x}}$ $\mathrm{Sr}_{\mathrm{x}} \mathrm{Co}_{\mathrm{y}} \mathrm{Fe}_{1-\mathrm{y}} \mathrm{O}_{3-\delta}$ can vary about one order of magnitude [181][188][227][228]. One strategy to improve performance of LSCF cathodes is the fabrication of composite electrodes with CGO [54][229], CGO/Ag [55] or SDC [230] or to obtain higher surface exchange coefficient $\mathrm{k}$ by impregnating LSCF with Pd [231].

Cathode performance can also be improved by substituting one or more of the elements in $\mathrm{Ln}_{1-\mathrm{x}} \mathrm{Sr}_{\mathrm{x}} \mathrm{Co}_{\mathrm{y}} \mathrm{Fe}_{1-\mathrm{y}} \mathrm{O}_{3-\delta}$. Enhanced performance at low temperatures $\left(\sim 600{ }^{\circ} \mathrm{C}\right)$ is obtained for $\mathrm{Ln}=\mathrm{Ce}$, Dy [232], whereas TEC is lowered for $\mathrm{Ln}=\mathrm{Nd}$ [233]. Reaction products with YSZ are less pronounced for $\mathrm{Ln}=\mathrm{Pr}, \mathrm{Nd}, \mathrm{Gd}$ [57]. On $\mathrm{CGO}$, no reaction products are found for $\mathrm{Ln}$ = La, Gd, Sm, Nd [234][235], although no distinct reaction products with LSGM are found, codiffusion into the electrolyte is detected [236]. Sr-doped lanthanum ferrites have also been investigated, since they have a lower TEC than LSCF [237], but they also form Sr- or La-zirconates with YSZ [238], which can be reduced by adding $\mathrm{Al}$ to $\mathrm{LaFe}_{1-\mathrm{x}} \mathrm{Al}_{\mathrm{x}} \mathrm{O}_{3}$ systems without $\mathrm{Sr}$ doping [239] or using $\mathrm{Ce}_{0.8} \mathrm{Sm}_{0.2} \mathrm{O}_{1.9}$ protection layers [238]. The conductivity is comparable to that of LSCF, and is enhanced by adding $\mathrm{Ni}$ [240][241], or replacing $\mathrm{Sr}$ with

Table 3. Coefficient of thermal expansion (TEC) $\left(30-1000{ }^{\circ} \mathrm{C}\right)$, electronic $\left(\sigma_{\mathrm{e}}\right)$ and ionic $\left(\sigma_{\mathrm{i}}\right)$ conductivity and bulk diffusion $\mathrm{D}$ as well as surface exchange coefficient $\mathrm{k}$ at $800^{\circ} \mathrm{C}$ for some SOFC cathode

\begin{tabular}{|c|c|c|c|c|c|}
\hline Material & $\mathrm{TEC} / 10^{-6} \mathrm{~K}^{-1}$ & $\sigma_{\mathrm{e}} /[\mathrm{S} / \mathrm{cm}]$ & $\sigma_{\mathrm{i}} /[\mathrm{S} / \mathrm{cm}]$ & $\mathrm{D} /\left[\mathrm{cm}^{2} / \mathrm{s}\right]$ & $\mathrm{k} /[\mathrm{cm} / \mathrm{s}]$ \\
\hline $\mathrm{La}_{0.65} \mathrm{Sr}_{0.35} \mathrm{MnO}_{3-\delta}$ & $\begin{array}{l}12.3[181] \\
(Y S Z: 11.0 \cdot[198])\end{array}$ & 102 [181] & $\begin{array}{l}1.7 \cdot 10^{-4} \\
{[181]}\end{array}$ & $\begin{array}{l}4 \cdot 10^{-14} \\
{[198]} \\
\left(\text { at } 900^{\circ} \mathrm{C}\right)\end{array}$ & $\begin{array}{l}5 \cdot 10^{-8} \\
{[198]} \\
\left(\text { at } 900^{\circ} \mathrm{C}\right)\end{array}$ \\
\hline $\mathrm{La}_{0.6} \mathrm{Sr}_{0.4} \mathrm{Co}_{0.2} \mathrm{Fe}_{0.8} \mathrm{O}_{3}$ & $\begin{array}{l}17.5 \text { [181] } \\
\text { (CGO: } 10.5 \text { [199]) }\end{array}$ & 302 [181] & $\begin{array}{l}8 \cdot 10^{-3} \\
{[181]}\end{array}$ & $\begin{array}{l}2.5 \cdot 10^{-8} \\
{[200]}\end{array}$ & $\begin{array}{l}5.6 \cdot 10^{-6} \\
{[200]}\end{array}$ \\
\hline
\end{tabular}


$\mathrm{Ni}$ [242], but is decreased by adding $\mathrm{Al}$ [243][244].

Another material that is investigated for cathodes is $\mathrm{Sm}_{1-\mathrm{x}} \mathrm{Sr}_{\mathrm{x}} \mathrm{CoO}_{3}$ (SSC) [202][245][246], showing lower overpotential than LSC [246]. Fabricating composites with the electrolyte material $\left(\mathrm{Ce}_{0.8}\right.$ $\left.\mathrm{Sm}_{0.2} \mathrm{O}_{19}\right)$, the interfacial resistances are reduced [247]. SSC is also used for single chamber SOFC applications [14][248].

Barium cobaltates $\mathrm{Ba}_{1-\mathrm{x}} \mathrm{Ln}_{\mathrm{x}} \mathrm{CoO}_{3}, \mathrm{Ln}=$ $\mathrm{La}, \mathrm{Pr}$ are studied on either $\mathrm{BaCeO}_{3}$ [245][249] or LSGM [250] based electrolytes and found to have less polarization losses than SSC for Ln = Pr [245], but higher overpotentials than SSC for $\mathrm{Ln}=\mathrm{La}$ [250].

\subsection{New Cathode Materials}

Pyrochlore ruthenates have been investigated with compositions of $\mathrm{Bi}_{2} \mathrm{Ru}_{2} \mathrm{O}_{7.3}$, $\mathrm{Pb}_{2} \mathrm{Ru}_{2} \mathrm{O}_{6.5}$ and $\mathrm{Y}_{2} \mathrm{Ru}_{2} \mathrm{O}_{7}$. Only the latter was found to be stable on CGO electrolytes, but additional doping with $\mathrm{SrO}$ is necessary in order to reach reasonable conductivity [251].

The search for new cathode materials for intermediate temperatures led to the discovery of $\mathrm{La}_{1-\mathrm{x}} \mathrm{Sr}_{\mathrm{x}} \mathrm{CuO}_{2.5-\delta}$. This material is a possible cathode candidate because it shows no reaction with YSZ, it exhibits high conductivity and gives reasonably low overpotential [252]. $\mathrm{La}_{2} \mathrm{Ni}_{1-\mathrm{x}} \mathrm{Cu}_{\mathrm{x}} \mathrm{O}_{4+\delta}$ on the other hand shows high diffusion and surface exchange coefficients, but rather low conductivity, comparable to LSM [253]. Composite cathodes of Ag and yttrium doped bismuth oxide show comparable performance to LSCF [54]. For $\mathrm{Y}_{1} \mathrm{Ba}_{2} \mathrm{Cu}_{3} \mathrm{O}_{7}$ an additional layer of $\mathrm{Pt}$ or $\mathrm{Ag}$ is needed to promote oxygen adsorption [254]. $\mathrm{Nd}_{2} \mathrm{NiO}_{4+\delta}$ cathodes show lower polarization resistance than LSM but longterm stability tests have not been performed [255].

In the search for new cathode materials based on perovskites a structural field map of perovskites, containing transition metal cations may be useful. In Fig. 12, the Coulomb potentials from the $\mathrm{A}$ and $\mathrm{B}$ cations in perovskites $\mathrm{ABO}_{3}$ are plotted as $\mathrm{Z}_{\mathrm{A}} / \mathrm{r}_{\mathrm{A}}$ and $\mathrm{Z}_{\mathrm{B}} / \mathrm{r}_{\mathrm{B}}$. Thereby $\mathrm{Z}_{\mathrm{A}}$ and $\mathrm{Z}_{\mathrm{B}}$ are the formal valence of the $A$ and $B$ cations and $r_{A}$ respectively $r_{B}$ are their ionic radii. The smaller the value of $\mathrm{Z}_{\mathrm{A}} / \mathrm{r}_{\mathrm{A}}$ along the ordinate is, the more itinerant the d-electrons of the perovskite become. Similarly the smaller the value $Z_{B} / r_{B}$ along the abscissa gets, the more itinerant the d-electrons of the perovskite are. The physical meaning of the parameter $Z_{A} / r_{A}$ is a measure for the perturbation of the covalent $\mathrm{B}-0$ bond and the parameter $\mathrm{Z}_{\mathrm{B}} / \mathrm{r}_{\mathrm{B}}$ is a measure for the Coulomb potential of the outermost d-electrons from the centre of the B ion. In this potential map, we find two well-defined regions. The region of compounds with localized electrons and that of itinerant electrons, both separated by the line in the graph [179][256]. The most interesting compounds and corresponding solid solutions are located with their potentials directly on, or close to the dividing line between these two regions. Along this line, we will find new catalysts as well as materials with interesting electrical properties such as high mixed electronic/ionic conductivity.

\section{Summary and Conclusions}

One of the main problems of SOFCs is the high operating temperature leading to a fast degradation rate of cell performance and the need for more expensive interconnect and sealing materials. The electrolyte resistance mainly determines the operating temperature of the cell. Two ways are possible to decrease the latter, either by decreasing the electrolyte thickness or by using alternative electrolyte materials with higher ionic conductivity. One of the materials that have been proposed for low tem-

\section{Structural Field Map [C $\left.\mathrm{N}_{\mathrm{A}}=12\right]$}

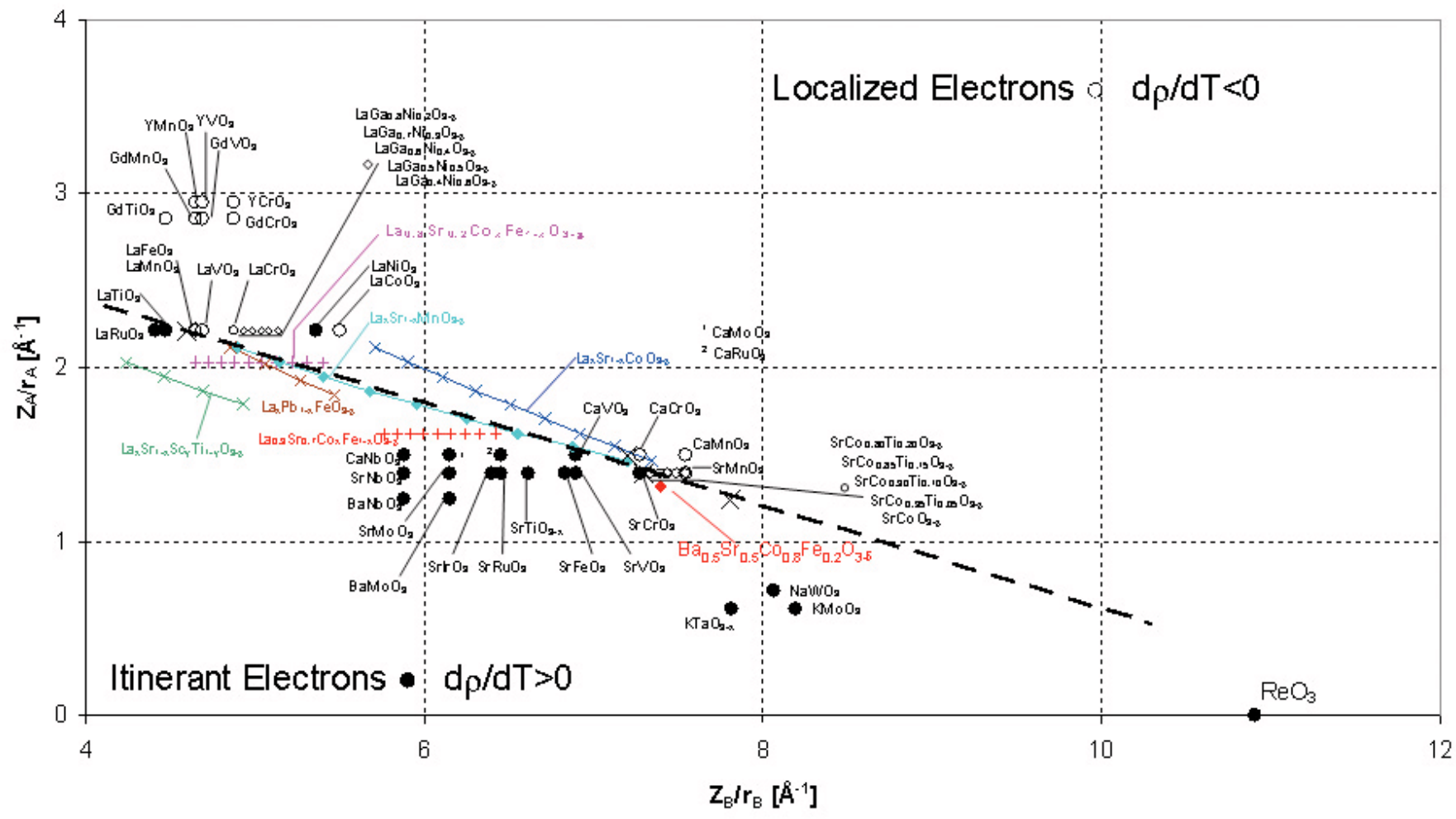

Fig. 12. Potential map of some perovskites useful in the search of new compounds. Compounds with interesting catalytic and electrical properties are located on, or close, to the line dividing the areas of compounds with semiconducting and metallic character, modified after [256]. 
perature fuel cells are ceria solid solutions with tri- or divalent cations. The aim of development of SOFC materials is towards lower operating temperatures from 500 to $800{ }^{\circ} \mathrm{C}$. Ceria composite electrolytes, especially in bi-layered configuration with a thin electron-blocking YSZ layer on anode or cathode support structures are promising alternatives to the pure load bearing YSZ electrolytes in planar configurations. Thin film techniques are used for the fabrication of such structures.

Anode materials with tailored catalytic activities towards reforming of hydrocarbons as well as robustness and high tolerance against oxidation/reduction cycles are needed. Anodes with sufficient sulphur tolerance up to levels of 20-50 ppm should be aimed for.

In addition, miniaturized SOFCs will require new thin film cathodes, electrolytes, and anodes with microstructures in the nanometre range as well as new support structures that can be micro-machined and bonded with methods from micro technology.

Cathodes with mixed electronic and ionic conductivity promise to reduce overpotentials especially for low and intermediate temperature use. Thereby special emphasis should be devoted to materials with high oxygen surface exchange coefficients in addition to high oxygen diffusivity. Structural field maps may help in the search of new catalytic materials and those with unusual high electronic and oxygen ion conductivity.

Received: October 27, 2004

[1] N.Q. Minh, J. Am. Ceram. Soc. 1993, 76(3), 563.

[2] K.L. Ley, M. Krumpelt, R. Kumar, J.H. Meiser, I. Bloom, J. Mater. Res. 1996, 11(6), 1489.

[3] K. Eichler, G. Solow, P. Otschik, W. Schaffrath, J. Eur. Ceram. Soc. 1999, 19(6-7), 1101.

[4] S.P. Simner, J.W. Stevenson, J. Power Sources 2001, 102(1-2), 310.

[5] N.F. Bessete, B.P. Borglum, H. Schichl, D.S. Schmidt, Siemens Power J. 2001, 1, 10.

[6] R.A. George, J. Power Sources 2000, 86(1-2), 134.

[7] J.P.P. Huijsmans, R.C. Huiberts, G.M. Christie, Fuel Cells Bul. 1999, 2(14), 5.

[8] M. Schmidt, Fuel Cells Bul. 1998, 1(1), 9.

[9] T. Doerk, H. Raak, S. Riggenbach, GWF Gas/Erdgas 2003, 144(12), 746.

[10] W. van Gool, Philips Res. Rep. 1965, 20, 81.

[11] C.K. Dyer, Nature 1990, 343, 547.

[12] T. Hibino, H. Iwahara, Chem. Lett. 1993, 7, 1131 .

[13] M. Goedickemeier, D. Nussbaum, C. Kleinlogel, L.J. Gauckler, in 192nd Meeting of Electrochemical Society, 1997, Paris, France: Electrochemical Society.
[14] T. Hibino, A. Hashimoto, T. Inoue, J. Tokuno, Y. Shin-ichiro, S. Mitsuru, Science 2000, 288, 2031.

[15] T. Hibino, A. Hashimoto, M. Yano, M. Suzuki, S. Yoshida, S. Mitsuru, J. Electrochem. Soc. 2002, 149(2), A133.

[16] S. Calabrese Barton, T. Patterson, E. Wang, T.F. Fuller, A.C. West, J. Power Sources 2001, 96(2), 329.

[17] M.A. Priestnall, V.P. Kotzeva, D.J. Fish, E.M. Nilsson, J. Power Sources 2002, 106(1-2), 21.

[18] B.C.H. Steele, J. Power Sources 1994, 49(1-3), 1

[19] S.J. Skinner, J.A. Kilner, Mater. Today 2003, 6(3), 30.

[20] S.C. Singhal, Solid State Ionics 2000, 135(1-4), 305

[21] S.P.S. Badwal, Solid State Ionics 2001, 143(1), 39.

[22] S.P.S. Badwal, Solid State Ionics 1992 52(1-3), 23.

[23] I.R. Gibson, G.P. Dransfield, J.T.S. Irvine, J. Eur. Ceram. Soc. 1998, 18(6), 661.

[24] F.T. Ciacchi, S.P.S. Badwal, J. Drennan, J. Eur. Ceram. Soc. 1991, 7(3), 185.

[25] S.P.S. Badwal, F.T. Ciacchi, S. Rajendran, J. Drennan, Solid State Ionics 1998, 109(3-4), 167.

[26] K. Kobayashi, H. Kuwajima, T. Masaki, Solid State Ionics 1981, 3-4, 489.

[27] F.M. Figueiredo, J.A. Labrincha, J.R. Frade, F.M.B. Marques, Solid State Ionics 1997, 101-103(Part 1), 343.

[28] S.P. Jiang, J.G. Love, J.P. Zhang, M. Hoang, Y. Ramprakash, A.E. Hughes, S.P.S. Badwal, Solid State Ionics 1999, 121(1-4), 1

[29] O. Yamamoto, Y. Takeda, R. Kanno, M. Noda, Solid State Ionics 1987, 22(2-3), 241.

[30] M. Dokiya, Solid State Ionics 2002 , 152-153, 383 .

[31] B. Steele, Comptes Rendus de l'Academie des Sciences - Series IIC - Chemistry 1998, l(9), 533.

[32] J. Will, A. Mitterdorfer, C. Kleinlogel, D. Perednis, L.J. Gauckler, Solid State Ionics 2000, 131(1-2), 79.

[33] H. Tu, U. Stimming, J. Power Sources 2004, 127(1-2), 284.

[34] H. Yokokawa, N. Sakai, T. Horita, K. Yamaji, Fuel Cells 2001, 1(2), 117.

[35] A. Boudghene Stambouli, E. Traversa, Renew. Sustain. Energy Rev. 2002, 6(5), 433.

[36] S.M. Haile, Acta Mater. 2003, 51(19), 5981.

[37] P. Shuk, H.-D. Wiemhofer, U. Guth, W. Gopel, M. Greenblatt, Solid State Ionics 1996, 89(3-4), 179.

[38] S.P.S. Badwal, F.T. Ciacchi, D. Milosevic, Solid State Ionics 2000, 136137, 91.

[39] M. Yashima, M. Kakihana, M. Yoshimura, Solid State Ionics 1996, 86-88(Part 2), 1131.
[40] O. Yamamoto, Y. Arati, Y. Takeda, N. Imanishi, Y. Mizutani, M. Kawai, Y. Nakamura, Solid State Ionics 1995, 79, 137.

[41] Y. Mizutani, M. Tamura, M. Kawai, O. Yamamoto, Solid State Ionics 1994, 72(Part 2), 271.

[42] T.I. Politova, J.T.S. Irvine, Solid State Ionics, in press.

[43] C.M. Kleinlogel, L.J. Gauckler, J. Electroceram. 2000, 5(3), 231.

[44] M. Mogensen, N.M. Sammes, G.A. Tompsett, Solid State Ionics 2000, 129(1-4), 63.

[45] B.C.H. Steele, Solid State Ionics 2000, 129(1-4), 95.

[46] H. Yahiro, K. Eguchi, H. Arai, Solid State Ionics 1989, 36(1-2), 71.

[47] K. Eguchi, T. Setoguchi, T. Inoue, H. Arai, Solid State Ionics 1992, 52(1-3), 165.

[48] T. Inoue, T. Setoguchi, K. Eguchi, H. Arai, Solid State Ionics 1989, 35(3-4), 285.

[49] D. Perez-Coll, P. Nunez, J.R. Frade, J.C.C. Abrantes, Electrochim. Acta 2003, 48(11), 1551.

[50] S. Zha, C. Xia, G. Meng, J. Power Sources 2003, 115(1), 44.

[51] Z. Tianshu, P. Hing, H. Huang, J. Kilner, Solid State Ionics 2002, 148(3-4), 567.

[52] J. Kilner, B.C.H. Steele, 'Nonstoichiometric oxides', Academic Press, New York, 1981.

[53] D. Schneider, M. Godickemeier, L.J. Gauckler, J. Electroceram. 1997, 1(2), 165.

[54] R. Doshi, V.L. Richards, J.D. Carter, X.P. Wang, M. Krumpelt, J. Electrochem. Soc. 1999, 146(4), 1273.

[55] S. Wang, T. Kato, S. Nagata, T. Honda, T. Kaneko, N. Iwashita, M. Dokiya, Solid State Ionics 2002, 146(3-4), 203.

[56] S. Wang, T. Kato, S. Nagata, T. Kaneko, N. Iwashita, T. Honda, M. Dokiya, Solid State Ionics 2002, 152-153, 477.

[57] L. Qiu, T. Ichikawa, A. Hirano, N. Imanishi, Y. Takeda, Solid State Ionics 2003, 158(1-2), 55.

[58] I. Riess, Solid State Ionics 2003, 157(14), 1 .

[59] S. Dikmen, P. Shuk, M. Greenblatt, Solid State Ionics 1998, 112(3-4), 299.

[60] J.C. Boivin, C. Pirovano, G. Nowogrocki, G. Mairesse, P. Labrune, G. Lagrange, Solid State Ionics 1998, 113 115,639 .

[61] F. Abraham, J.C. Boivin, G. Mairesse, G. Nowogrocki, Solid State Ionics 1990, 40-41(2), 934

[62] R.N. Vannier, R.J. Chater, S.J. Skinner, J.A. Kilner, G. Mairesse, Solid State Ionics 2003, 160(3-4), 327.

[63] C. Pirovano, R.N. Vannier, E. Capoen, G. Nowogrocki, J.C. Boivin, G. Mairesse, M. Anne, E. Dooryhee, P. Strobel, Solid State Ionics 2003, 159 (12), 167.

[64] G. Mairesse, Comptes Rendus de l'Academie des Sciences - Series IIC Chemistry 1999, 2(11-13), 651. 
[65] N.M. Sammes, G.A. Tompsett, H. Nafe, F. Aldinger, J. Eur. Ceram. Soc. 1999, 19(10), 1801.

[66] R.M. Ormerod, Chem. Soc. Rev. 2002 $32,17$.

[67] B.C.H. Steele, A. Heinzel, Nature 2001, 414(6861), 345

[68] N.P. Brandon, S. Skinner, B.C.H. Steele, Ann. Rev. Mater. Res. 2003, 33, 183.

[69] J. Wiemhofer, H.-D. Weitkamp, Solid State Ionics 2002, 154-155, 597.

[70] J. Will, M.K.M. Hruschka, L. Gubler, L.J. Gauckler, J. Am. Ceram. Soc. 2001, 84(2), 328-32.

[71] H. Sasaki, S. Otoshi, M. Suzuki, T. Sogi, A. Kajimura, N. Sugiuara, M. Ippommatsu, Solid State Ionics 1994, 72, 253.

[72] H.R. Gruner, H. Tannenberger, Proceedings of the First European Solid Oxide Fuel Cell Forum, 1994, Ed. U. Bossel. European SOFC Forum Lucerne, Switzerland, 1994, 611.

[73] K. Honegger, E. Batawi, C. Sprecher, R. Diethelm, Proceedings of SOFC V (Aachen, Germany, 1997), Eds. U. Stimming, S.C. Singhal, H. Tagawa, W. Lehner. Electrochemical Society, Pennington, NJ, 1997, 321.

[74] D. Perednis, L.J. Gauckler, Solid State Ionics 2004, 166(3-4), 229.

[75] D. Perednis, L.J. Gauckler, in 8th International Symposium on Solid Oxide Fuel Cells (SOFC), 2003, Paris, France: The Electrochemical Society.

[76] D. Perednis, L.J. Gauckler, in 8th Solid Oxide Fuel Cell ECS Symposium. 2003: Electrochemical Society.

[77] D. Perednis, L.J. Gauckler, Solid State Ionics 2004, 166(3-4), 229.

[78] A. Tsoga, A. Gupta, A. Naoumidis, P. Nikolopoulos, Acta Mater. 2000, 48(1819), 4709

[79] H. Chang, in 5th Annual Small Fuel Cells 2003 - Small Fuel Cells for Portable Applications, 2003

[80] F.M.B. Marques, L.M. Navarro, Solid State Ionics 1996, 90(1-4), 183.

[81] F.M.B. Marques, L.M. Navarro, Solid State Ionics 1997, 100(1-2), 29.

[82] S.P.S. Badwal, K. Foger, Ceram. Int. 1996, 22(3), 257.

[83] B.C.H. Steele, Curr. Opin. Solid State Mat. Sci. 1996, 1(5), 684.

[84] V. Kozhukharov, N. Brashkova, M. Ivanova, J. Carda, M. Machkova, Bol. Soc. Esp. Ceram. Vidr. 2002, 41(5), 471.

[85] H. Iwahara, H. Uchida, S. Tanaka, Solid State Ionics 1983, 9-10(Part 2), 1021.

[86] J.F. Liu, A.S. Nowick, Solid State Ionics 1992, 50(1-2), 131.

[87] N. Bonanos, Solid State Ionics 1992, 5356(Part 2), 967.

[88] R.C.T. Slade, N. Singh, Solid State Ionics 1993, 61(1-3), 111.

[89] H. Iwahara, T. Yajima, T. Hibino, H. Ushida, J. Electrochem. Soc. 1993, 140(6), 1687.
[90] H. Iwahara, T. Shimura, H. Matsumoto, Electrochemistry 2000, 68(3), 154.

[91] H. Iwahara, T. Mori, T. Hibino, Solid State Ionics 1995, 79, 177.

[92] K.D. Kreuer, Ann. Rev. Mater. Res. 2003, 33, 333.

[93] G. Ma, T. Shimura, H. Iwahara, Solid State Ionics 1999, 120(1-4), 51.

[94] K.D. Kreuer, Solid State Ionics 1999, 125(1-4), 285.

[95] K.H. Ryu, S.M. Haile, Solid State Ionics 1999, 125(1-4), 355.

[96] H.G. Bohn, T. Schober, J. Am. Ceram. Soc. 2000, 83(4), 768.

[97] K.D. Kreuer, S. Adams, W. Munch, A. Fuchs, U. Klock, J. Maier, Solid State Ionics 2001, 145(1-4), 295.

[98] H. Fujii, Y. Katayama, T. Shimura, H. Iwahara, J. Electroceram. 1998, 2(2), 119.

[99] W. Grover Coors, J. Power Sources 2003, 118(1-2), 150.

[100] W. Munch, K.-D. Kreuer, G. Seifert, J. Maier, Solid State Ionics 2000, 136-137, 183.

[101] T. Setoguchi, K. Okamoto, K. Eguchi, H. Arai, J. Electrochem. Soc. 1992, 139(10), 2875.

[102] F. Tietz, F.J. Dias, D. Simwonis, D. Stover, J. Eur. Ceram. Soc. 2000, 20(8), 1023.

[103] T. Fukui, K. Murata, S. Ohara, H. Abe, M. Naito, K. Nogi, J. Power Sources 2004, 125(1), 17.

[104] A.C. Muller, D. Herbstritt, E. IversTiffee, Solid State Ionics 2002, 152, 537.

[105] J.T.S. Irvine, A. Sauvet, Fuel Cells 2001, 1(3-4), 205.

[106] J. Van Herle, S. Diethelm, J. Sfeir, R. Ihringer, 'Materials for methane-fueled SOFC systems', in Euro Ceramics Vii, Pt 1-3, 2002, p. 1213.

[107] W.Z.Zhu, S.C. Deevi, Mater. Sci. Eng. A 2003, 362(1-2), 228.

[108] A. Atkinson, S. Barnett, R.J. Gorte, J.T.S. Irvine, A.J. McEvoy, M. Mogensen, S.C. Singhal, J. Vohs, Nat. Mater. 2004, 3(1), 17.

[109] B.C.H. Steele, Solid State Ionics 1996 , 86-8, 1223.

[110] J.P.P. Huijsmans, Curr. Opin. Solid State Mat. Sci. 2001, 5(4), 317

[111] M. Mogensen, K.V. Jensen, M.J. Jorgensen, S. Primdahl, Solid State Ionics 2002, 150(1-2), 123.

[112] H.H. Mobius, J. Solid State Electrochem. 1997, l(1), 2.

[113] S. Wang, T. Kato, S. Nagata, T. Honda, T. Kaneko, N. Iwashita, M. Dokiya, $J$. Electrochem. Soc. 2002, 149(7), A927.

[114] C. Xia, M. Liu, Solid State Ionics 2002, 152-153, 423

[115] S. Zha, W. Rauch, M. Liu, Solid State Ionics 2004, 166(3-4), 241.

[116] X.Q. Huang, Z.G. Liu, Z. Lu, L. Pei, R.B. Zhu, Y.Q. Liu, J.P. Miao, Z.G. Zhang, W.H. Su, J. Phys. Chem. Solids 2003, 64(12), 2379.
[117] X. Huang, Z. Lu, L. Pei, Z. Liu, Y. Liu, R. Zhu, J. Miao, Z. Zhang,W. Su, J. Alloy Compd. 2003, 360(1-2), 294.

[118] E.P. Murray, S.J. Harris, H.W. Jen, J. Electrochem. Soc. 2002, 149(9), A1127.

[119] S. Baron, N. Brandon, A. Atkinson, B. Steele, R. Rudkin, J. Power Sources 2004, 126(1-2), 58 .

[120] L. Zhong, M. Liu, G.L. Wei, K. Chuang, Chin. J. Chem. Eng. 2003, 11(3), 245.

[121] A. Weber, B. Sauer, A.C. Muller, D. Herbstritt, E. Ivers-Tiffee, Solid State Ionics 2002, 152, 543.

[122] B.C.H. Steele, Nature 1999, 400(6745), 619.

[123] G.J. Saunders, J. Preece, K. Kendall, J. Power Sources 2004, 131(1-2), 23.

[124] T. Takeguchi, Y. Kani, T. Yano, R. Kikuchi, K. Eguchi, K. Tsujimoto, Y. Uchida, A. Ueno, K. Omoshiki, M. Aizawa, J. Power Sources 2002, 112(2), 588.

[125] C.M. Chun, J.D. Mumford, T.A. Ramanarayanan, J. Electrochem. Soc. $\mathbf{2 0 0 0}$ 147(10), 3680.

[126] T. Takeguchi, R. Kikuchi, T. Yano, K. Eguchi, K. Murata, Catal. Today 2003, 84(3-4), 217.

[127] Y. Matsuzaki, I. Yasuda, Solid State Ionics 2000, 132(3-4), 261.

[128] O. Costa-Nunes, J.M. Vohs, R.J. Gorte, J. Electrochem. Soc. 2003, 150(7), A858.

[129] I.A. Proctor, A.L. Hopkin, R.M. Ormerod, Ionics 2003, 9(3-4), 242.

[130] M.T. Tavares, I. Alstrup, C.A.A. Bernardo, Mater. Corros. 1999, 50(12), 681.

[131] H. Kim, C. Lu, W.L. Worrell, J.M. Vohs, R.J. Gorte, J. Electrochem. Soc. 2002 , 149(3), A247.

[132] Z. Lu, L. Pei, T.M. He, X.Q. Huang, Z.G. Liu, Y. Ji, X.H. Zhao, W.H. Su, J. Alloy Compd. 2002, 334, 299.

[133] C. Lu, W.L. Worrell, J.M. Vohs, R.J. Gorte, J. Electrochem. Soc. 2003, 150(10), A1357.

[134] E. Ramirez-Cabrera, A. Atkinson, D. Chadwick, Solid State Ionics 2000, 136 137, 825.

[135] E. Ramirez-Cabrera, A. Atkinson, D. Chadwick, Appl. Catal. B-Environ. 2004, 47(2), 127.

[136] O.A. Marina, C. Bagger, S. Primdahl, M. Mogensen, Solid State Ionics 1999, 123(1-4), 199.

[137] O.A. Marina, M. Mogensen, Appl. Catal. A-Gen. 1999, 189(1), 117.

[138] S. Zhao, R.J. Gorte, Appl. Catal. A-Gen. 2003, 248(1-2), 9 .

[139] T. Horita, K. Yamaji, T. Kato, N. Sakai, H. Yokokawa, J. Power Sources 2004, 131(1-2), 299.

[140] R.J. Gorte, H. Kim, J.M. Vohs, J. Power Sources 2002, 106(1-2), 10.

[141] C. Lu, W.L. Worrell, C. Wang, S. Park, H. Kim, J.M. Vohs, R.J. Gorte, Solid State Ionics 2002, 152, 393.

[142] M.B. Jörger, PhD Thesis ETH No. 15351, 2004. 
[143] T. Hibino, A. Hashimoto, M. Yano, M. Suzuki, M. Sano, Electrochim. Acta 2003, 48(17), 2531.

[144] S. McIntosh, J.M. Vohs, R.J. Gorte, Electrochem. Solid State Lett. 2003, 6(11), A240.

[145] A.J. Feighery, J.T.S. Irvine, D.P. Fagg, A. Kaiser, J. Solid State Chem. 1999, 143(2), 273

[146] P. Holtappels, J. Bradley, J.T.S. Irvine, A. Kaiser, M. Mogensen, J. Electrochem. Soc. 2001, 148(8), A923.

[147] S. Tao, J.T.S. Irvine, J. Solid State Chem. 2002, 165(1), 12.

[148] M. Mori, Y. Hiei, H. Itoh, G.A Tompsett, N.M. Sammes, Solid State Ionics 2003, 160(1-2), 1.

[149] A. Kelaidopoulou, A. Siddle, A.L. Dicks, A. Kaiser, J.T.S. Irvine, Fuel Cells 2001, 1(3-4), 226.

[150] D. Skarmoutsos, F. Tietz, P. Nikolopoulos, Fuel Cells 2001, 1(3-4), 243.

[151] N. Kiratzis, P. Holtappels, D.E. Hatchwell, M. Mogensen, J.T.S. Irvine, Fuel Cells 2001, 1(3-4), 211.

[152] A. Kelaidopoulou, A. Siddle, A.L. Dicks, A. Kaiser, J.T.S. Irvine, Fuel Cells 2001, 1(3-4), 219.

[153] B.A. Boukamp, Nat. Mater. 2003, 2(5), 294.

[154] J.J. Sprague, H.L. Tuller, J. Eur. Ceram Soc. 1999, 19(6-7), 803.

[155] H. Yokokawa, N. Sakai, T. Kawada, M. Dokiya, Solid State Ionics 1992, 52(1-3), 43.

[156] G. Pudmich, B.A. Boukamp, M. Gonzalez-Cuenca, W. Jungen, W. Zipprich, F. Tietz, Solid State Ionics 2000, 135(1-4), 433.

[157] P. Holtappels, F.W. Poulsen, M. Mogensen, Solid State Ionics 2000, 135(14), 675.

[158] A.-L. Sauvet, J. Fouletier, J. Power Sources 2001, 101(2), 259.

[159] A. Lashtabeg, J.T.S. Irvine, A. Feighery, Ionics 2003, 9(3-4), 220

[160] C.M. Reich, A. Kaiser, J.T.S. Irvine, Fuel Cells 2001, 1(3-4), 249.

[161] A. Kaiser, J.L. Bradley, P.R. Slater, J.T.S. Irvine, Solid State Ionics 2000, 135(1-4), 519.

[162] P.R. Slater, J.T.S. Irvine, Solid State Ionics 1999, 124(1-2), 61.

[163] P.R. Slater, J.T.S. Irvine, Solid State Ionics 1999, 120(1-4), 125.

[164] S. Primdahl, J.R. Hansen, L. GrahlMadsen, P.H. Larsen, J. Electrochem. Soc. 2001, 148(1), A74.

[165] S. Tanasescu, D. Berger, D. Neiner, N.D. Totir, Solid State Ionics 2003, 157(1-4), 365.

[166] P. Vernoux, M. Guillodo, J. Fouletier, A. Hammou, Solid State Ionics 2000, 135(1-4), 425.

[167] J. Sfeir, P.A. Buffat, P. Mockli, N. Xanthopoulos, R. Vasquez, H.J. Mathieu, J. Van herle, K.R. Thampi, J. Catal. 2001, 202(2), 229.
[168] J. Sfeir, 'Alternative Anode Materials for Methane Oxidation in Solid Oxide Fuel Cells', PhD Thesis, 2002.

[169] A.L. Sauvet, J. Fouletier, F. Gaillard, M. Primet, J. Catal. 2002, 209(1), 25.

[170] A.L. Sauvet, J. Fouletier, Electrochim. Acta 2001, 47(6), 987.

[171] M. Gonzalez-Cuenca, W. Zipprich, B.A. Boukamp, G. Pudmich, F. Tietz, Fuel Cells 2001, 1(3-4), 256.

[172] O.A. Marina, N.L. Canfield, J.W. Stevenson, Solid State Ionics 2002, 149(1-2), 21.

[173] J. Canales-Vazquez, S.W. Tao, J.T.S. Irvine, Solid State Ionics 2003, 159 (1-2), 159

[174] S.Q. Hui, A. Petric, J. Electrochem. Soc 2002, 149(1), J1.

[175] S.Q. Hui, A. Petric, Mater. Res. Bull. 2002, 37(7), 1215.

[176] S.Q. Hui, A. Petric, J. Eur. Ceram. Soc. 2002, 22(9-10), 1673.

[177] P.R. Slater, D.P. Fagg, J.T.S. Irvine, J. Mater. Chem. 1997, 7(12), 2495.

[178] S.W. Tao, J.T.S. Irvine, Nat. Mater 2003, 2(5), 320.

[179] T. Nakamura, G. Petzow, L.J. Gauckler, Mater. Res. Bull. 1979, 14(5), 649.

[180] A. Mitterdorfer, L.J. Gauckler, Solid State Ionics 1998, 111(3-4), 185.

[181] H. Ullmann, N. Trofimenko, F. Tietz, D. Stover, A. Ahmad-Khanlou, Solid State Ionics 2000, 138(1-2), 79.

[182] B.C.H. Steele, Solid State Ionics 2000 , 134(1-2), 3

[183] A.J. McEvoy, J. Mater. Sci. 2001, 36(5), 1087.

[184] J.M. Ralph, A.C. Schoeler, M. Krumpelt, J. Mater. Sci. 2001, 36(5), 1161.

[185] R.M. Ormerod, Chem. Soc. Rev. 2003 32(1), 17.

[186] A. Weber, E. Ivers-Tiffee, J. Power Sources 2004, 127(1-2), 273.

[187] J. Will, R. Stadler, M.K.M. Hruschka, L.J. Gauckler, 'Fabrication Processes for Electroceramic Components, in Oxygen Ion and Mixed Conductors and Their Technological Applications', Eds. H.L. Tuller et al., Kluwer Academic Press, 2000, p. 165.

[188] S. Wang, M. Katsuki, M. Dokiya, T. Hashimoto, Solid State Ionics 2003, 159(1-2), 71.

[189] H.U. Anderson, Solid State Ionics 1992 , 52(1-3), 33 .

[190] J.A. Kilner, R.A. DeSouza, I.C. Fullarton, Solid State Ionics 1996, 86-8, 703.

[191] H.J.M. Bouwmester, A.J. Burggraaf, in the CRC Handbook of Solid-State Electrochemistry, Ed. H.J.M. Bouwmester, CRC Press, Boca Raton, 1997, p. 481.

[192] M. Katsuki, S. Wang, M. Dokiya, T. Hashimoto, Solid State Ionics 2003, 156(3-4), 453.

[193] S.B. Adler, J.A. Lane, B.C.H. Steele, J. Electrochem. Soc. 1996, 143(11), 3554.

[194] S.B. Adler, J.A. Lane, B.C.H. Steele, J. Electrochem. Soc. 1997, 144(5), 1884.
[195] M. Liu, J. Winnick, J. Electrochem. Soc. 1997, 144(5), 1881

[196] M.L. Liu, J. Winnick, Solid State Ionics 1999, 118(1-2), 11.

[197] G.W. Coffey, L.R. Pederson, P.C. Rieke, J. Electrochem. Soc. 2003, 150(8), A1139.

[198] S. Carter, A. Selcuk, R.J. Chater, J. Kajda, J.A. Kilner, B.C.H. Steele, Solid State Ionics 1992, 53-56(Part 1), 597.

[199] H. Hayashi, M. Kanoh, C.J. Quan, H. Inaba, S. Wang, M. Dokiya, H. Tagawa, Solid State Ionics 2000, 132(3-4), 227.

[200] S.J. Benson, R.J. Chater, J.A. Kilner, Electrochemical Society Proceedings 1997, 97-24, 596.

[201] N.T. Hart, N.P. Brandon, M.J. Day, J.E. Shemilt, J. Mater. Sci. 2001, 36(5), 1077.

[202] J.M. Ralph, C. Rossignol, R. Kumar, J. Electrochem. Soc. 2003, 150(11), A1518.

[203] M.C. Brant, T. Matencio, L. Dessemond, R.Z. Domingues, Chem. Mat. 2001, 13(11), 3954

[204] M.J.L. Ostergard, C. Clausen, C. Bagger, M. Mogensen, Electrochim. Acta 1994, 40(12), 1971.

[205] H. Kamata, A. Hosaka, J. Mizusaki, H. Tagawa, Solid State Ionics 1998, 106 (3-4), 237.

[206] K. Barthel, S. Rambert, S. Siegmann, J. Therm. Spray Technol. 2000, 9(3), 343.

[207] K. Hayashi, M. Hosokawa, T. Yoshida, Y. Ohya, Y. Takahashi, O. Yamamoto, H. Minoura, Mater. Sci. Eng. B 1997, 49(3), 239.

[208] N.T. Hart, N.P. Brandon, M.J. Day, N. Lapena-Rey, J. Power Sources 2002, 106(1-2), 42

[209] S.P. Yoon, J. Han, S.W. Nam, T.-H. Lim, I.-H. Oh, S.-A. Hong, Y.-S. Yoo, H.C. Lim, J. Power Sources 2002, 106(1-2), 160.

[210] H. Zhao, L. Huo, S. Gao, J. Power Sources 2004, 125(2), 149

[211] K. Murata, M. Shimotsu, J. Ceram. Soc. Jpn. 2002, 110(7), 618 .

[212] S. Hashimoto, H. Iwahara, J. Electroceram. 2000, 4(1), 225.

[213] G.C. Kostogloudis, C. Ftikos, J. Eur. Ceram. Soc. 1999, 19(4), 497.

[214] G.C. Kostogloudis, N. Vasilakos, C. Ftikos, J. Eur. Ceram. Soc. 1997, 17(12), 1513.

[215] Y. Sakaki, Y. Takeda, A. Kato, N. Imanishi, O. Yamamoto, M. Hattori, M. Iio, Y. Esaki, Solid State Ionics 1999, 118(3-4), 187.

[216] H.-R. Rim, S.-K. Jeung, E. Jung, J.-S. Lee, Mater. Chem. Phys. 1998, 52(1), 54.

[217] S. Faaland, M.A. Einarsrud, K. Wiik, T. Grande, R. Hoier, J. Mater. Sci. 1999 , 34(23), 5811.

[218] X. Huang, J. Liu, Z. Lu, W. Liu, L. Pei T. He, Z. Liu, W. Su, Solid State Ionics 2000, 130(3-4), 195.

[219] X. Huang, L. Pei, Z. Liu, Z. Lu, Y. Sui, Z. Qian, W. Su, J. Alloy Compd. 2002 345(1-2), 265 
[220] C.Y. Huang, T.J. Huang, J. Mater. Sci. 2002, 37(21), 4581.

[221] D. Kuscer, M. Hrovat, J. Holc, S. Bernik, D. Kolar, J. Power Sources 1998, 71(1-2), 195.

[222] I. Riess, M. Godickemeier, L.J. Gauckler, Solid State Ionics 1996, 90(1-4), 91.

[223] T. Horita, K. Yamaji, N. Sakai, H. Yokokawa, A. Weber, E. Ivers-Tiffee, Solid State Ionics 2000, 133(3-4), 143.

[224] H. Uchida, S. Arisaka, M. Watanabe, Solid State Ionics 2000, 135(1-4), 347.

[225] T. Inagaki, K. Miura, H. Yoshida, R. Maric, S. Ohara, X. Zhang, K. Mukai, T. Fukui, J. Power Sources 2000, 86(1-2), 347.

[226] R. Maric, S. Ohara, T. Fukui, H. Yoshida, M. Nishimura, T. Inagaki, K. Miura, J. Electrochem. Soc. 1999, 146(6), 2006.

[227] A. Petric, P. Huang, F. Tietz, Solid State Ionics 2000, 135(1-4), 719.

[228] L.-W. Tai, M.M. Nasrallah, H.U. Anderson, D.M. Sparlin, S.R. Sehlin, Solid State Ionics 1995, 76(3-4), 259.

[229] V. Dusastre, J.A. Kilner, Solid State Ionics 1999, 126(1-2), 163.

[230] Y. Matsuzaki, I. Yasuda, Solid State Ionics 2002, 152, 463.

[231] M. Sahibzada, S.J. Benson, R.A. Rudkin, J.A. Kilner, Solid State Ionics 1998, 113-115, 285.

[232] J. Gao, X. Liu, D. Peng, G. Meng, Catal. Today 2003, 82(1-4), 207.

[233] N. Dasgupta, R. Krishnamoorthy, K.T. Jacob, Mater. Sci. Eng. B 2002, 90(3), 278.

[234] W. Chen, T. Wen, H. Nie, R. Zheng, Mater. Res. Bull. 2003, 38(8), 1319.
[235] W.X. Chen, H.W. Nie, W.H. Huang, R. Zheng, H.Y. Tu, Z.Y. Lu, T.L. Wen, $J$. Mater. Sci. Lett. 2003, 22(9), 651.

[236] G.C. Kostogloudis, C. Ftikos, A. Ahmad-Khanlou, A. Naoumidis, D. Stover, Solid State Ionics 2000, 134(1-2), 127.

[237] S.P. Simner, J.F. Bonnett, N.L. Canfield, K.D. Meinhardt, J.P. Shelton, V.L. Sprenkle, J.W. Stevenson, J. Power Sources 2003, 113(1), 1.

[238] S.P. Simner, J.P. Shelton, M.D. Anderson, J.W. Stevenson, Solid State Ionics 2003, 161(1-2), 11.

[239] D. Kuscer, J. Holc, M. Hrovat, D. Kolar, J Eur. Ceram. Soc. 2001, 21(10-11), 1817.

[240] R. Chiba, F. Yoshimura, Y. Sakurai, Solid State Ionics 2002, 152-153, 575.

[241] S.P. Simner, J.F. Bonnett, N.L. Canfield, K.D. Meinhardt, V.L. Sprenkle, J.W. Stevenson, Electrochem. Solid St. 2002, 5(7), A173.

[242] R. Chiba, F. Yoshimura, Y. Sakurai, Solid State Ionics 1999, 124(3-4), 281.

[243] G.W. Coffey, J. Hardy, L.R. Pedersen, P.C. Rieke, E.C. Thomsen, M. Walpole, Solid State Ionics 2003, 158(1-2), 1.

[244] J. Holc, D. Kuscer, M. Hrovat, S. Bernik, D. Kolar, Solid State Ionics 1997, 95(3-4), 259.

[245] T. Hibino, A. Hashimoto, M. Suzuki, M. Sano, J. Electrochem. Soc. 2002 149(11), A1503.

[246] H. Fukunaga, M. Koyama, N. Takahashi, C. Wen, K. Yamada, Solid State Ionics 2000, 132(3-4), 279.

[247] C. Xia, W. Rauch, F. Chen, M. Liu, Solid State Ionics 2002, 149(1-2), 11.
[248] B.E. Bürgler, M. Siegrist, L.J. Gauckler, in Fuel Cell Forum. 2004. Lucerne, Switzerland.

[249] M. Koyama, C. Wen, K. Yamada, J. Electrochem. Soc. 2000, 147(1), 87.

[250] T. Ishihara, S. Fukui, H. Nishiguchi, Y. Takita, Solid State Ionics 2002, 152-153, 609.

[251] J.M. Bae, B.C.H. Steele, J. Electroceram. 1999, 3(1), 37.

[252] H.-C. Yu, K.-Z. Fung, Mater. Res. Bull. 2003, 38(2), 231.

[253] E. Boehm, J.-M. Bassat, M.C. Steil, P. Dordor, F. Mauvy, J.-C. Grenier, Solid State Sci. 2003, 5(7), 973.

[254] C.L. Chang, T.C. Lee, T.J. Huang, J. Solid State Electrochem. 1998, 2(5), 291.

[255] F. Mauvy, J.-M. Bassat, E. Boehm, J.-P. Manaud, P. Dordor, J.-C. Grenier, Solid State Ionics 2003, 158(1-2), 17.

[256] after K. Kamata, T. Nakamura, K. Sata, Bulletin of Tokyo Institute of Technology 1974, 541.67:549.51(220), $74 \mathrm{ff}$. 